\title{
Petrogenesis of rare-metal pegmatites in high-grade metamorphic terranes: A case study from the Lewisian Gneiss Complex of north-west Scotland
}

\author{
R.A. Shaw ${ }^{\mathrm{a}, *}$, K.M. Goodenough ${ }^{\mathrm{b}}$, N.M.W. Roberts ${ }^{c}$, M.S.A. Horstwood ${ }^{\mathrm{c}}$, S.R. Chenery ${ }^{\mathrm{a}}$, A.G. Gunn ${ }^{\mathrm{a}}$ \\ ${ }^{a}$ British Geological Survey, Environmental Science Centre, Nicker Hill, Keyworth, Nottingham NG12 5GG, UK \\ ${ }^{\mathrm{b}}$ British Geological Survey, West Mains Road, Edinburgh EH9 3LA, UK

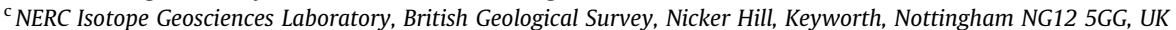

\section{A R T I C L E I N F O}

\section{Article history:}

Received 4 February 2016

Revised 5 May 2016

Accepted 4 June 2016

Available online 11 June 2016

\section{Keywords:}

Lewisian Gneiss Complex

Rare-metal pegmatite

Laxfordian

Geochronology

\section{A B S T R A C T}

Many rare metals used today are derived from granitic pegmatites, but debate continues about the origin of these rocks. It is clear that some pegmatites represent the most highly fractionated products of a parental granite body, whilst others have formed by anatexis of local crust. However, the importance of these two processes in the formation of rare-metal pegmatites is not always evident.

The Lewisian Gneiss Complex of NW Scotland comprises Archaean meta-igneous gneisses which were highly reworked during accretional and collisional events in the Palaeoproterozoic (Laxfordian orogeny). Crustal thickening and subsequent decompression led to melting and the formation of abundant granitic and pegmatitic sheets in many parts of the Lewisian Gneiss Complex. This paper presents new petrological, geochemical and age data for those pegmatites and shows that, whilst the majority are barren biotite-magnetite granitic pegmatites, a few muscovite-garnet (rare-metal) pegmatites are present. These are mainly intruded into a belt of Palaeoproterozoic metasedimentary and meta-igneous rocks known as the Harris Granulite Belt.

The rare-metal pegmatites are distinct in their mineralogy, containing garnet and muscovite, with local tourmaline and a range of accessory minerals including columbite and tantalite. In contrast, the biotitemagnetite pegmatites have biotite and magnetite as their main mafic components. The rare-metal pegmatites are also distinguished by their bulk-rock and mineral chemistry, including a more peraluminous character and enrichments in $\mathrm{Rb}, \mathrm{Li}, \mathrm{Cs}, \mathrm{Be}, \mathrm{Nb}$ and $\mathrm{Ta}$. New U-Pb ages (c. 1690-1710 Ma) suggest that these rare-metal pegmatites are within the age range of nearby biotite-magnetite pegmatites, indicating that similar genetic processes could have been responsible for their formation.

The peraluminous nature of the rare-metal pegmatites strongly points towards a metasedimentary source. Notably, within the Lewisian Gneiss Complex, such pegmatites are only found in areas where a metasedimentary source is available. The evidence thus points towards all the Laxfordian pegmatites being formed by a process of crustal anatexis, with the formation of rare-metal pegmatites being largely controlled by source composition rather than solely by genetic process. This is in keeping with previous studies that have also challenged the widely accepted model that all rare-metal pegmatites are formed by fractionation from a parental granite, and raises questions about the origin of other mineralised pegmatites worldwide.

(c) 2016 British Geological Survey, NERC. Published by Elsevier B.V. This is an open access article under the CC BY license (http://creativecommons.org/licenses/by/4.0/).

\section{Introduction}

Granitic pegmatites are important sources of rare metals, such as $\mathrm{Ta}, \mathrm{Nb}, \mathrm{Li}, \mathrm{Cs}$ and the rare earth elements (REE), that are being increasingly used in new and green technologies. Pegmatite

\footnotetext{
* Corresponding author. Tel.: +44 1159363010

E-mail address: rashaw@bgs.ac.uk (R.A. Shaw).
}

research, and the debate surrounding their origin and classification, has interested geoscientists for well over a century. Early workers were divided on the origin of pegmatites; some favoured a purely igneous origin (De Beaumont, 1847; Hitchcock, 1883), whilst others relied on hydrothermal processes to explain their formation (Hunt, 1871). However, it was Brögger (1890) who first suggested that a complex interplay of igneous and hydrothermal processes is responsible for their formation. A comprehensive 
review of the history of pegmatite research is given in London (2008).There are many ways to classify pegmatites, with one of the simplest being a division into barren and rare-metal pegmatites. A rare-metal pegmatite is defined as "a pegmatite that hosts appreciable beryl, lithium aluminosilicates, and phosphates other than apatite, oxides other than magnetite or ilmenite, and other rarer minerals" (London, 2014).

Regardless of the mechanism of formation, the rare metal budget of a pegmatite is ultimately defined by both the composition and volume of source material from which the parent granite pluton is derived, with or without the addition of material external to the system (Novák et al., 2012). Rare-metal pegmatites can be broadly divided into two geochemical groups, or families: pegmatites enriched in niobium, yttrium and fluorine (NYF), which have a compositional affinity with alkaline A-type granites generated by melting of lower continental crust and/or mantle; and pegmatites enriched in lithium, caesium and tantalum (LCT), which are derived from peraluminous S-type granites associated with the melting of schists and gneisses of sedimentary origin (Černý et al., 2012a). However, within these two families exists a varied array of sub-classes and sub-types, which are described in detail by Černý and Ercit (2005).

There are currently two hypotheses that aim to explain how pegmatite-forming melts are generated: (1) extended fractional crystallisation of a granitic magma at the scale of a pluton, and (2) direct formation by low-degree partial melting of crustal rocks, typically in the presence of fluids (London, 2005; Martin and De Vito, 2005). In practice, these hypotheses represent two endmembers and many pegmatites may be formed by a combination of crustal melting and subsequent fractionation of small magmatic bodies. Examples of rare-metal pegmatites formed by extended fractional crystallisation of larger granitic intrusions are well documented from: Separation Lake, Canada (Pan and Breaks, 1997; Tindle and Breaks, 2000); Yichun, China (Belkasmi et al., 2000); the North Pilbara Craton, Western Australia (Sweetapple and Collins, 2002); and Indian Hill, southern California (Walawender, 2003). However, an increasing number of studies describe felsic pegmatites that are considered to be derived by direct partial melting rather than by fractional crystallisation of a parent granite. Examples include the Münchberg Massif, Germany (Franz and Smelik, 1995); Brattstrand Bluffs, East Antarctica (Fitzsimons, 1996); Larsemann Hills, East Antarctica (Carson et al., 1997); Urdach and Espéchère, in the western Pyrénées (Pin et al., 2006); the Fraser Lake area of Northern Saskatchewan, Canada (McKechnie et al., 2012); and the Moldanubian domain of the Bohemian Massif, Czech Republic (Melleton et al., 2012). In many cases granitic pegmatites are described as being derived by extended fractional crystallisation of a fertile parent granite, even where a parent granite body remains enigmatic (Crouse and Černý, 1972; Jahns and Ewing, 1976; Stilling et al., 2006). This raises an interesting question - if a pegmatite cannot be proven to be spatially, temporally or genetically related to a parent granite body is it reasonable to make the assumption that a granitic body exists unseen at depth? Or is it equally reasonable to suggest that the pegmatites formed by direct crustal melting and pooling of small melt bodies with some in situ fractionation? Making the distinction between the two processes can be challenging, particularly as all rare-metal pegmatites have compositions that are consistent with significant levels of fractionation (Martin and de Vito, 2005). Whilst in some areas the process may be clear, in others a detailed understanding of tectonic setting and magmatic chronology is required to understand the origin of pegmatites.

For example, rare-metal pegmatites associated with postcollisional, Pan-African granitoids in Nigeria have been shown to post-date the main phase of peraluminous magmatism by at least $90 \mathrm{Ma}$, creating a 'pegmatite conundrum' (Goodenough et al.,
2014). This temporal disjunction is particularly interesting given current ideas about the rapid rates of cooling of pegmatite intrusions. Several authors (Chakoumakos and Lumpkin, 1990; Černý and Ercit, 2005; London, 2008) have suggested that the temperature of a pegmatite body may drop below the liquidus in a matter of days or weeks, and will have solidified in a few hundreds of years. Webber and Simmons (2007) determined that the $100 \mathrm{~m}$ - thick Tanco pegmatite solidified over a period of 700-1000 years. Globally, major pegmatites such as Tanco (Canada), Greenbushes and Wodgina (Australia) represent important resources of rare metals such as $\mathrm{Ta}, \mathrm{Nb}, \mathrm{Li}, \mathrm{Cs}$ and $\mathrm{Sn}$. Of these Tanco and Wodgina have no clear link to a granite body.

Tanco, a highly fractionated, complexly-zoned LCT pegmatite of the rare-element class (Stilling et al., 2006) was discovered during the late $1920 \mathrm{~s}$. Since the $1960 \mathrm{~s}$ it has produced over four million tonnes of Ta-ore at an average grade of $0.2 \mathrm{wt} . \% \mathrm{Ta}_{2} \mathrm{O}_{5}$. Latterly Tanco has been an important producer of Cs and refractory spodumene (Martins et al., 2013). The pegmatite (2640 \pm 7 Ma) (Baadsgaard and Černý, 1993) is hosted by metagabbroic and amphibolitic rocks of the Bird River Greenstone Belt (2731 \pm $1-2706 \pm 23 \mathrm{Ma}$ ) (Gilbert, 2007, 2008). The greenstone belt is bounded to the north by the Maskwa Lake Batholith $(2725 \pm 6 \mathrm{Ma})$ (Wang, 1993) and to the south by the Lac du Bonnet batholith (2660 $\pm 3 \mathrm{Ma}$ ) (Wang, 1993), although no clear temporal or genetic link has been made between Tanco and either of these large granitic bodies (Gilbert, 2008).

The Greenbushes pegmatite in south-western Australia is a large, complexly-zoned LCT pegmatite of Archaean age (c. $2527 \mathrm{Ma}$ ) (Partington et al., 1995) which provided a large proportion of the world's tantalum for many years. The pegmatite is intruded into the Balingup metamorphic belt, a gneissgreenstone belt on the edge of the Yilgarn craton. Although there are several granitoid plutons in the area, these pre-date the pegmatite body by at least $50 \mathrm{Ma}$ and are not considered to be genetically related (Partington et al., 1995).

In the UK, pegmatites of Palaeoproterozoic age occur throughout the Lewisian Gneiss Complex in north-west Scotland and the Hebrides (Fettes et al., 1992; Castro, 2004; Watkins et al., 2007; Goodenough et al., 2013). The pegmatites are intruded into both typical Archaean TTG gneisses, and into arc-related meta-igneous and metasedimentary rocks (Park et al., 2001; Kinny and Friend, 2005). The predominance of meta-igneous rocks in the Lewisian significantly reduces the potential for the formation of large bodies of fertile S-type granite, and thus LCT pegmatites might not be expected within the Lewisian. In fact, although there is no evidence of any fertile parent granite, LCT-type rare-metal pegmatites are found in some areas. The broad tectonic setting and general age relationships of the pegmatites are relatively well understood (Park et al., 2001; Goodenough et al., 2013; Mason, 2015) and the area therefore represents an excellent natural laboratory to investigate the controls on pegmatite magmatism. Using wholerock geochemistry, detailed petrography and mineral chemistry from pegmatites across the Lewisian Gneiss Complex, with a particular focus on rare-metal-type pegmatites found in the Harris Granulite Belt (HGB) on South Harris, we aim to test the hypothesis that in the absence of a parental granite, small-scale partial melting of local crust can produce not only 'standard' granitic pegmatites, but also rare-metal pegmatites.

\section{Geological setting: the Lewisian Gneiss complex}

The Lewisian Gneiss Complex of north-west Scotland represents the margin of the North Atlantic Craton, comprising Archaean TTG gneisses that were variably reworked during the Palaeoproterozoic (Peach et al., 1907; Sutton and Watson, 1951). It crops out both on 
the west coast of the Scottish mainland and on the islands of the Outer Hebrides, and has been divided by recent workers into a number of separate terranes (Kinny and Friend, 2005; Love et al., 2010) (Fig. 1) although the exact details of those terranes and their structural relationships continue to be debated (Park, 2005; Wheeler et al., 2010; Mason, 2012).

The majority of the Lewisian gneisses were formed, deformed and metamorphosed to high grades during the Archaean (Sutton and Watson, 1951; Giletti et al., 1961; Kinny and Friend, 2005; Wheeler et al., 2010; Zirkler et al., 2012). Much of the region was subsequently affected by magmatism, amphibolite-facies metamorphism and deformation associated with collisional events during the Palaeoproterozoic Laxfordian orogeny (c. 1900-1670 Ma) (Sutton and Watson, 1951; Moorbath and Park, 1972; Kinny and Friend, 2005; Love et al., 2010; Goodenough et al., 2013). The Laxfordian orogeny comprise a number of events, the evidence for which varies across the Lewisian Gneiss Complex. The latter stages of the Laxfordian orogeny were marked by crustal melting and abundant granite magmatism in many parts of the Lewisian Gneiss Complex; this magmatic event is the subject of this paper.
The most-studied part of the Lewisian Gneiss Complex is the Assynt terrane on the Scottish mainland. Here, Archaean granulite-facies assemblages are well-preserved in the TTG gneisses, with limited Laxfordian reworking that is focused along discrete shear zones (Sutton and Watson, 1951; Tarney and Weaver, 1987; Kinny and Friend, 2005; Wheeler et al., 2010; Zirkler et al., 2012; MacDonald et al., 2015). Although the terrane is dominated by TTG gneisses, mafic to ultramafic and metasedimentary pods are found in a number of locations within the gneisses (Davies, 1974; Cartwright et al., 1985; Kinny and Friend, 2005; Goodenough et al., 2010). In this terrane, evidence for the Laxfordian orogeny is restricted to discrete amphibolite-facies shear zones in the gneisses. Magmatism associated with the Laxfordian event orogeny is restricted to a few narrow granite and granitic pegmatite sheets, largely intruded into the shear zones that form the terrane boundaries (Goodenough et al., 2010).

To the north of the Assynt terrane, the Rhiconich terrane was affected by significant Laxfordian reworking and is migmatitic in nature, with pervasive sheets of Laxfordian granite and granitic pegmatite throughout (Sutton and Watson, 1951; Beach et al.,

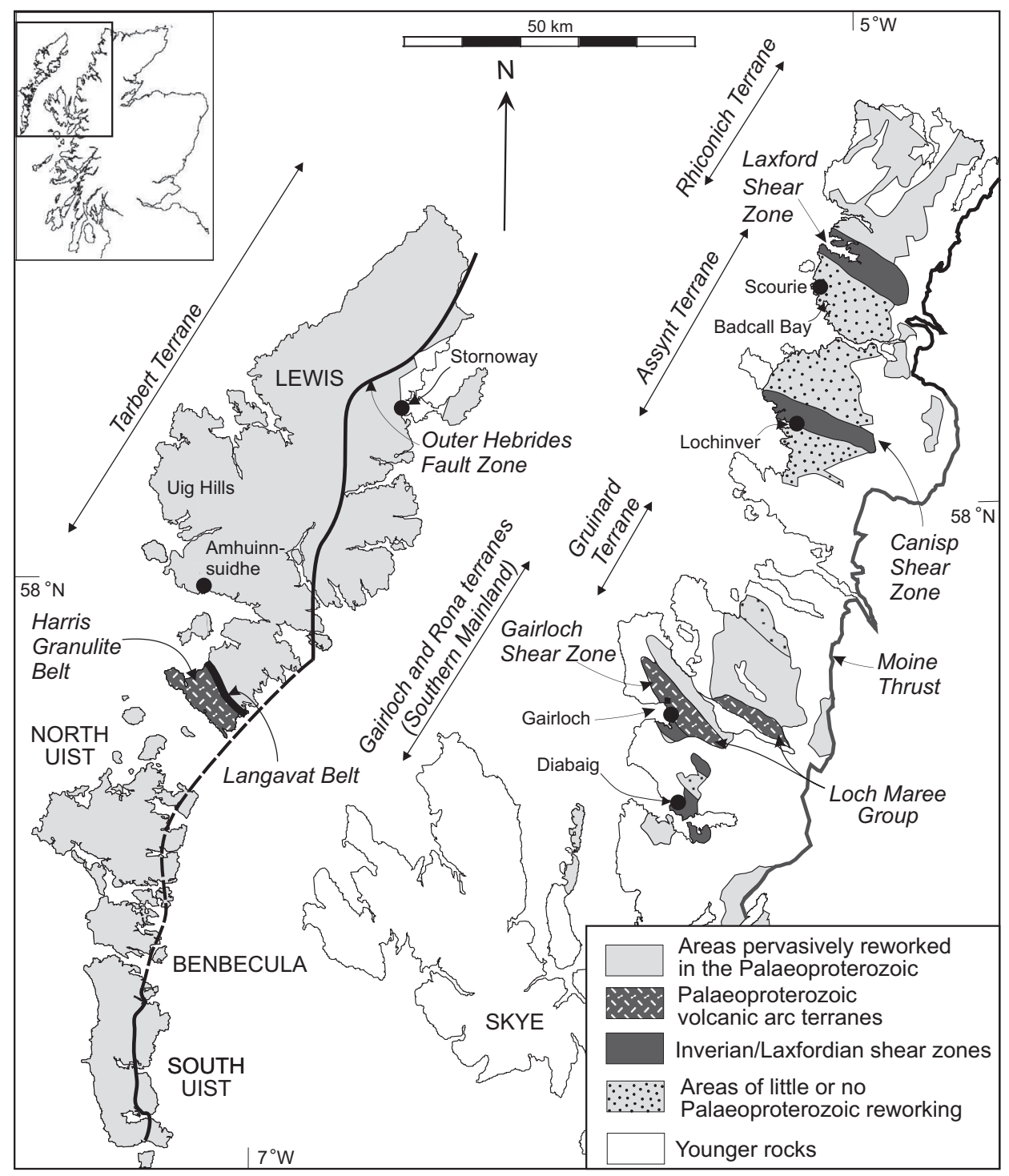

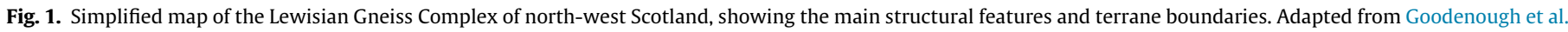
(2013). 
1974). These formed in two episodes: mildly alkaline granite intrusion at 1880-1850 Ma; and a migmatite and pegmatite-forming event at c. 1770-1790 Ma (Friend and Kinny, 2001; Goodenough et al., 2013). The earlier episode is considered to relate to active subduction and accretion, whereas the later one is largely postdeformational and thought to relate to decompression melting following an episode of collision and crustal thickening (Park 2005; Goodenough et al. 2013). Amalgamation of the Assynt and Rhiconich terranes occurred prior to pegmatite formation, with only the more fertile amphibolite-facies gneisses of the Rhiconich terrane subsequently melting (Goodenough et al. 2010).

Two Laxfordian magmatic events can also be recognised south of the Assynt terrane on the mainland. An important component of the Lewisian Gneiss Complex in this area is the Loch Maree Group, a Palaeoproterozoic volcanosedimentary package intruded by c. 1900 Ma granodioritic-tonalitic gneisses, and considered to represent a Palaeoproterozoic arc accreted to the continental margin relatively soon after formation (Park et al., 2001).

Laxfordian granite and pegmatite sheets are relatively rare in the Gruinard terrane and the Loch Maree Group but are common in the Gairloch and Rona terranes (Peach, 1913; Park, 2002; Love et al., 2010). These pegmatites are associated with the latest, low-temperature deformational phase in their host rocks, and are considered to have formed during post-collisional extension and decompression after continental collision (Park et al. 2001). They are dated at c. $1695 \mathrm{Ma}$ (Park et al., 2001), indicating that collision and crustal thickening were most probably diachronous across the mainland Lewisian Gneiss Complex. The Outer Hebrides are also made up of Archaean gneisses variably affected by Palaeoproterozoic reworking (Fig. 1), although the exact correlation of Hebridean and mainland terranes is still a matter of debate (Whitehouse and Bridgwater, 2001; Mason and Brewer, 2004; Love et al., 2010; Mason, 2015). The northern part of the Outer Hebrides (the Tarbert terrane) comprises Archaean gneisses that have been extensively reworked in the Palaeoproterozoic and intruded by granitic pegmatite sheets. This terrane contains the most significant development of Laxfordian magmatism in the Lewisian Gneiss Complex, the Uig Hills Granite Complex (Myers, 1971), dated at c. $1670 \mathrm{Ma}$ (Friend and Kinny, 2001). On the island of South Harris, the Roineabhal terrane (comprising the South Harris Igneous Complex and the metasedimentary Langavat and Leverburgh belts; Kinny and Friend (2005)) is considered to represent an island arc terrane, formed at c. $1900 \mathrm{Ma}$ (Whitehouse and Bridgwater, 2001; Mason et al., 2004a). The Roineabhal terrane has been divided into two separate parts (Mason et al., 2004b). The south-western part, the Harris Granulite Belt, includes both the metamorphosed gabbroic to anorthositic plutonic rocks of the South Harris Igneous Complex and the metasedimentary rocks of the Leverburgh Belt (Fig. 2). To the north-east lies the intensely deformed Langavat Belt, which represents a major shear zone in which metasedimentary rocks and Archaean orthogneisses are strongly interleaved (Mason et al. 2004b). The rocks of the Harris Granulite Belt were metamorphosed at high temperatures (granulite facies) shortly after formation (Cliff et al., 1998; Hollis et al., 2006; Baba et al., 2012) and were subsequently accreted to the margin of the Tarbert terrane by thrusting along the Langavat Belt (Mason, 2012). Granitic pegmatites within the Langavat Belt are strongly deformed and are dated at c. 1681-1657 Ma (Mason et al., 2004b; Kelly et al., 2008). These pegmatites are thus coeval with those in the Tarbert terrane to the north and with the southern mainland terranes, but they are unusual in that they have been affected by significant deformation.

In contrast, the granitic pegmatites within the Harris Granulite Belt are unusually large (up to $30 \mathrm{~m}$ across), sharply bounded, and cross-cut the main fabric in their host rocks. This group includes

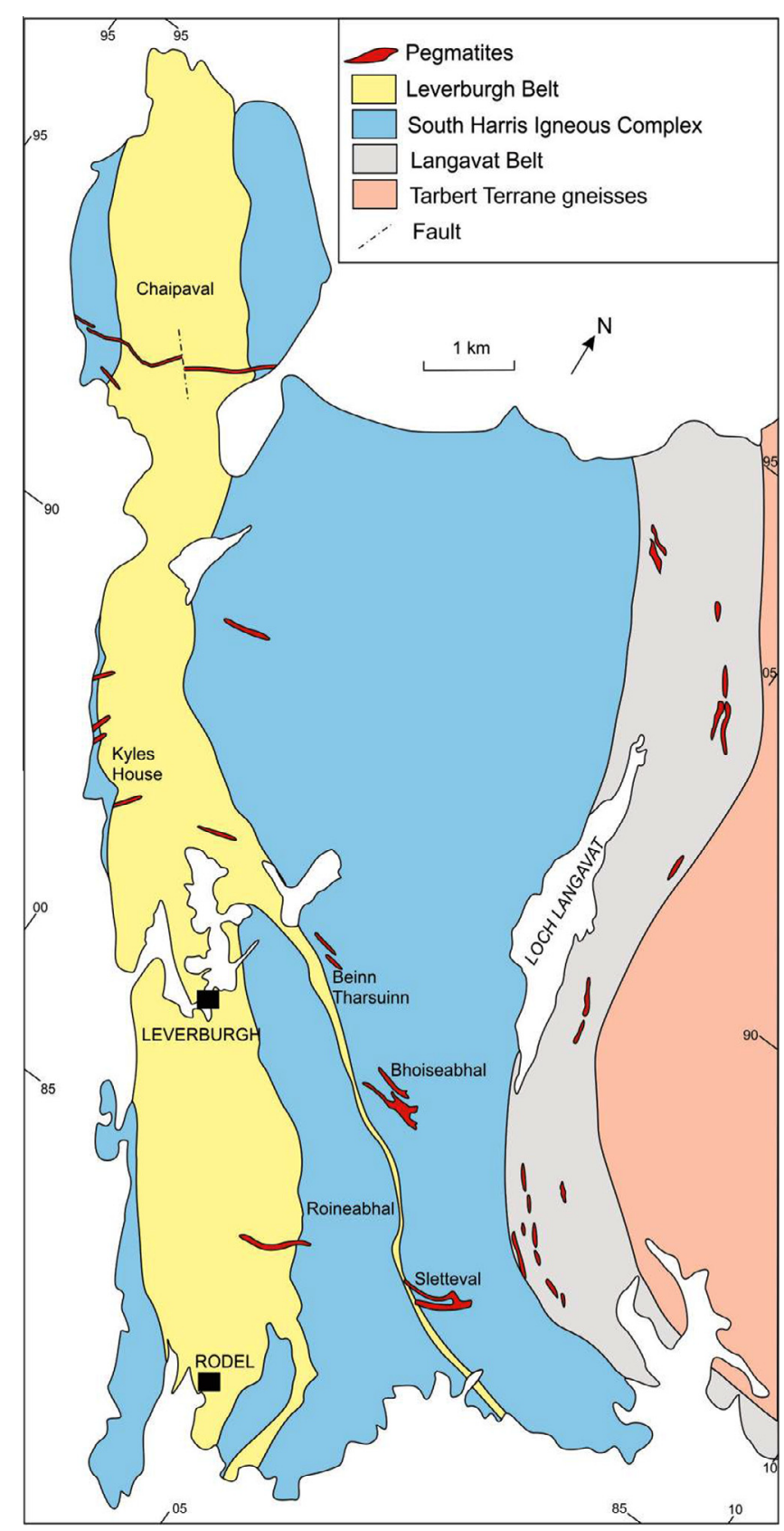

Fig. 2. Simplified geological map of South Harris, Outer Hebrides, showing the approximate location of pegmatites in the Langavat Belt, Leverburgh Belt and South Harris Igneous Complex (SHIC). After Fettes et al. (1992).

some rare-metal pegmatites (von Knorring and Dearnley, 1959). They have not previously been dated by modern methods.

Further south in the Outer Hebrides, Archaean gneisses have been extensively reworked during the Laxfordian event with intrusion of granitic and pegmatitic sheets (Love et al., 2010). As on the mainland, the Laxfordian events in the Outer Hebrides are interpreted in terms of an initial subduction-accretion period at $\mathrm{c}$. 1900-1850 Ma, followed by a period of continental collision and crustal thickening with crustal melting and migmatite-pegmatite formation during decompression at 1700-1650 Ma (Mason, 2015).

As described above, Laxfordian granites and pegmatites are particularly well developed in the Rhiconich and Tarbert terranes where they form a network of intrusive sheets within the TTG gneisses. Although the intrusions in these terranes appear to be 
Table 1

A summary of available ages for Lewisian pegmatites in the Outer Hebrides.

\begin{tabular}{|c|c|c|c|c|c|}
\hline Locality & Age (Ma) & System & Method & Phase & Reference and uncertainty level \\
\hline Chaipaval & $1690 \pm 39$ & $\mathrm{~Pb}-\mathrm{Pb}$ & LA-ICP-MS (weighted average) & Col & $1 ; 2 \mathrm{~s}$ \\
\hline Chaipaval & $1712 \pm 36$ & $\mathrm{U}-\mathrm{Pb}$ & LA-ICP-MS (regression) & Mnz & $1 ; 2 \mathrm{~s}$ \\
\hline Chaipaval & $1517 \pm 35$ & $\mathrm{U}-\mathrm{Pb}$ & LA-ICP-MS (regression) & $\mathrm{Xtm}$ & $1 ; 2 \mathrm{~s}$ \\
\hline Chaipaval & $\begin{array}{l}1570 \pm 80 \\
1610 \pm 70\end{array}$ & $\mathrm{Rb}-\mathrm{Sr}$ & ID-TIMS (mineral age) & Ms & $2 ; 2 \mathrm{~s}$ \\
\hline Sletteval & $\begin{array}{l}1530 \pm 60 \\
1450 \pm 60\end{array}$ & $\mathrm{Rb}-\mathrm{Sr}$ & ID-TIMS (mineral age) & $\mathrm{Bt}$ & $2 ; 2 \mathrm{~s}$ \\
\hline Chaipaval & 1570 & $\mathrm{~K}-\mathrm{Ar}$ & ID-TIMS (mineral age) & Ms & $2 ; “ \pm 5 \% ” 1 s ?$ \\
\hline Chaipaval & 1490 & $\mathrm{U}-\mathrm{Pb}$ & ID-TIMS & $\mathrm{Ur}$ & 3; unknown \\
\hline Chaipaval & $1565 \pm 100$ & $\mathrm{~Pb}-\mathrm{Pb}$ & ID-TIMS & Mnz & $4 ; 5 ;$ unknown \\
\hline Loch a'Sgurr & $1565 \pm 100$ & $\mathrm{~Pb}-\mathrm{Pb}$ & ID-TIMS & $\mathrm{Ur}$ & $4 ; 5 ;$ unknown \\
\hline Langavat Belt & $\begin{array}{l}1669 \pm 3 \\
1681 \pm 2\end{array}$ & $\mathrm{~Pb}-\mathrm{Pb}$ & $\begin{array}{l}\text { SIMS } \\
\text { (weighted average) }\end{array}$ & Zrn & $6 ; 2 \mathrm{~s}$ \\
\hline Langavat Belt & $1656 \pm 2$ & $\mathrm{U}-\mathrm{Pb}$ & $\begin{array}{l}\text { TIMS } \\
\text { (regression) }\end{array}$ & Zrn & $7 ; 2 \mathrm{~s}$ \\
\hline Langavat Belt & $1675 \pm 2$ & $\mathrm{~Pb}-\mathrm{Pb}$ & $\begin{array}{l}\text { TIMS } \\
\text { (single fraction) }\end{array}$ & Zrn & $8 ; 2 \mathrm{~s}$ \\
\hline Uig Hills Granite Complex & $1750 \pm 34$ & $\mathrm{Rb}-\mathrm{Sr}$ & $\begin{array}{l}\text { ID-TIMS } \\
\text { (isochron) }\end{array}$ & Whole-rock & 9 \\
\hline Uig Hills Granite Complex & $1715 \pm 20 / 10$ & $\mathrm{U}-\mathrm{Pb}$ & $\begin{array}{l}\text { ID-TIMS } \\
\text { (regression) }\end{array}$ & Zrn & 9; "Uncertainties visually estimated from Fig. 2" \\
\hline
\end{tabular}

Mineral abbreviations from Siivola and Schmid (2007), except Ur (uraninite) and Col (columbite).

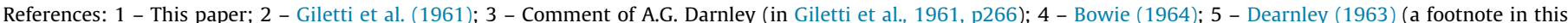

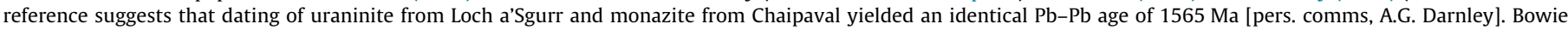

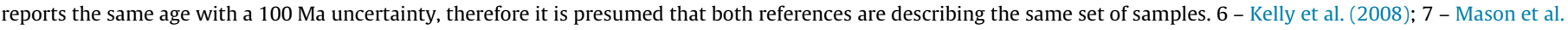
(2004); 8 - Mason and Brewer (2005) and; 9 - van Breeman et al. (1971).

of different ages, their modes of formation can be considered to be broadly similar. They have been described as migmatite complexes (Myers, 1971) and have generally been considered as formed by anatexis of crustal material. Field observations such as irregular and/or gradational contacts with the country rock and partially disaggregated country rock enclaves within their margins support these conclusions (Myers, 1971; Goodenough et al., 2013). In the Outer Hebrides, these field observations are corroborated by $\mathrm{Nd}$ isotope data that show the granitic sheets to have similar Nd isotope compositions to the Archaean gneisses (Taylor et al., 1984; Cliff et al., 1998). However, geochemical models and partial melting experiments have indicated that the granites and pegmatites of the Rhiconich terrane are unlikely to be derived solely by melting of the local TTG gneisses, and that introduction of a K-rich fluid is required (Fettes et al., 1992; Castro, 2004; Watkins et al., 2007).

The least studied among all the Laxfordian pegmatites of the Lewisian Gneiss Complex are the rare-metal pegmatites of the Harris Granulite Belt. There has been little consideration of the origin of these pegmatites in the wider Lewisian context, and so they represent an excellent case study for the controls on rare metal enrichment. Key questions include the age of these pegmatites and how they relate to the Laxfordian events recognised in other terranes; and whether their unusual rare-metal mineralogy corresponds to different compositions that cannot be explained by melting of local crustal material.

\section{Field relationships}

Fieldwork for this project entailed study and sampling of pegmatites from all the terranes described above except those of the southern Outer Hebrides. Observed field relationships are summarised in this section, in which the pegmatites are broadly divided into five spatial groups. The ages assigned to each group are based on the most reliable data currently available, although it is important to note that the small number of available dates may mask a much larger spread in pegmatite age. A summary of available ages for Lewisian pegmatites in the Outer Hebrides is given in Table 1.
(1) The pegmatites of the Rhiconich terrane, and sparse pegmatites in the Assynt terrane, dated at 1790-1770 Ma (Goodenough et al., 2013).

(2) The pegmatites of the southern mainland terranes, including those within the Tollie Antiform (Holland and Lambert, 1995), which are dated at c. 1695 Ma (Park et al., 2001).

(3) The pegmatites of the Tarbert terrane and Langavat Belt, dated at 1681-1657 Ma (Mason et al., 2004b; Kelly et al., 2008)

(4) The pegmatites of the Harris Granulite Belt, whose age has not been determined by modern methods, and which include a number of rare-metal pegmatites (von Knorring and Dearnley, 1959). These differ from almost all other Lewisian pegmatites in that they are intruded into meta-igneous and metasedimentary island arc rocks, rather than into TTG gneisses.

(5) The pegmatites of the southern islands in the Outer Hebrides, which have not been studied in detail and are not discussed further here.

\subsection{Rhiconich and Assynt terranes}

The Rhiconich and Assynt terranes are separated by a major WNW-trending, Palaeoproterozoic shear zone within the Lewisian Gneiss Complex, known as the Laxford Shear Zone (LSZ) (Coward, 1990; Goodenough et al., 2010). To the north of the LSZ migmatitic granodioritic gneisses, of the Rhiconich terrane, contain abundant granitic pegmatitic dykes. Pegmatites typically trend parallel to the host-rock fabric, but are locally cross-cutting, and are largely undeformed. Contacts with the host-rock are typically irregular and vary from sharp to gradational. The pegmatites form anastomosing networks with individual branches reaching about $1 \mathrm{~m}$ in width. Pegmatites from this area are predominantly composed of quartz and alkali feldspars with variable amounts of biotite. Rare, small aggregates of magnetite and biotite are found within the margins of the pegmatites, close to the contact with the hostrock. The grain size of the pegmatites is highly variable but locally very coarse with feldspar crystals up to $20 \mathrm{~cm}$ in length. 
South of the LSZ, in the TTG gneisses of the Assynt terrane, Laxfordian granitic pegmatites are rare. Only one pegmatite in this terrane was sampled, a particularly distinctive, thin but laterally extensive pegmatite at Badcall Bay (Fig. 1). The pegmatite is very coarse-grained and steeply dipping; with very sharp but irregular contacts with the host-rock. Despite the high degree of
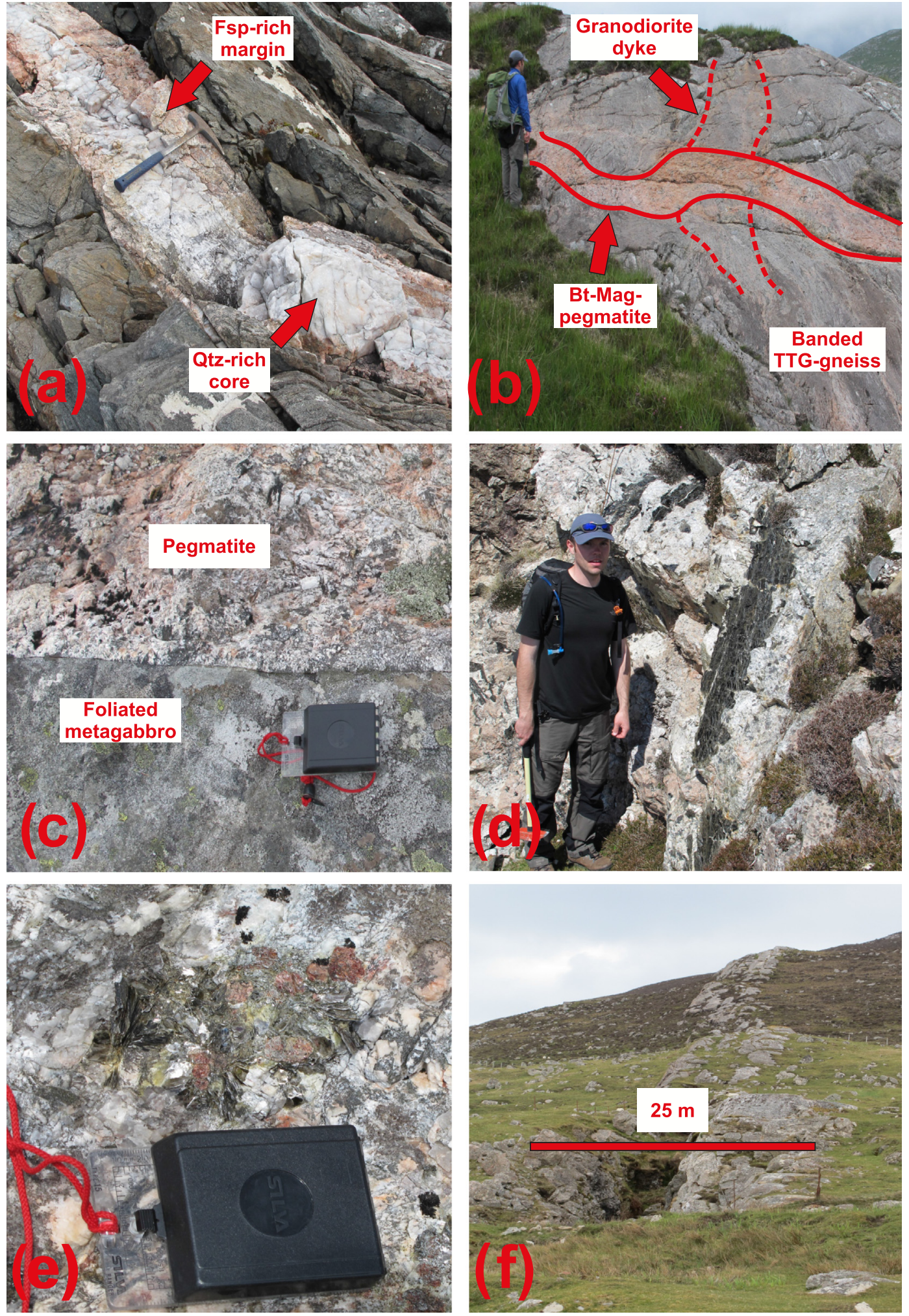

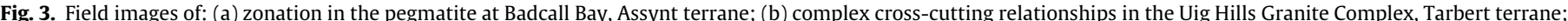

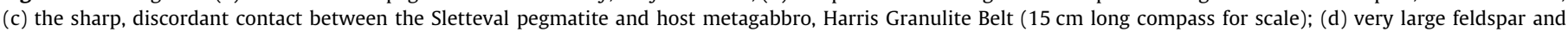

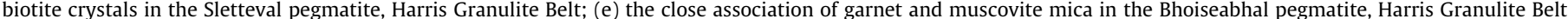
(15 cm long compass for scale); (f) the Chaipaval pegmatite near Northton, Harris Granulite Belt. 
heterogeneity the pegmatite is well zoned with clearly defined marginal areas richer in dark-pink albitic feldspar, and a milkyquartz-rich core (Fig. 3a). Thick books of muscovite and biotite mica are also present in the marginal zones of the pegmatite. Field relationships demonstrate that the pegmatite clearly cross-cuts Laxfordian shear zones (MacDonald et al., 2013).

\subsection{Southern mainland}

The southern mainland region includes areas around Gairloch, Diabaig and the shores of Loch Maree (Fig. 1). In the area around Gairloch, Laxfordian granitic sheets and pegmatites are common in proximity to a large-scale, NW-trending, Proterozoic fold in TTG gneisses known as the Tollie Antiform (Holland and Lambert, 1995). The boundaries between the antiform and the surrounding host-rocks are marked by zones of brittle-ductile deformation, the Grenvillian (c.1000 Ma) Leth-chreige crush belt (Sherlock et al., 2008) to the north and the Creag Bhan crush belt to the south (Park, 2002). The fold itself consists of a shallowdipping northern limb composed of dioritic orthogneiss and a steeply dipping southern limb comprising potassium-rich, quartzo-feldspathic orthogneiss (Park, 2002). Granitic pegmatites in this area occur as very coarse-grained sheets or pods and have sharp but irregular contacts with the host-rock. They are largely undeformed and typically cross-cut the host-rock foliation but are locally foliation parallel. However, within the Leth-chreige crush belt, pegmatites show evidence of brittle-ductile deformation and pervasive alteration that has remobilised trace elements including the light rare earth elements (LREE) in an irregular way (Owen, 2013). The pegmatites are quartz and K-feldspar-rich with variable amounts of biotite. Large aggregates of magnetite (up to $2 \mathrm{~cm}$ across) are present in some of the pegmatite margins, close to the contact with the host-rock gneiss.

The Diabaig area lies on the northern shores of Loch Torridon (Fig. 1). Diabaig area pegmatites are predominantly composed of quartz and K-feldspar with minor biotite and magnetite. The dykes mostly occur as sheets and thin veins between $5 \mathrm{~cm}$ and $5 \mathrm{~m}$ wide. Contacts with the host-rock gneiss vary from sharp to diffuse and irregular.

The Loch Maree Group (LMG), a Palaeoproterozoic island arc terrane, is composed of a series of NW-trending metasedimentary rocks, including schistose semipelites, and narrow bands of siliceous, graphitic and carbonaceous metasediments interlayered with metavolcanic amphibolites (Park, 2002). Pegmatites are rare within the Loch Maree Group, but on the northern shore of Loch Maree strongly foliated amphibolitic and gneissic host-rocks are intruded by a series of NNW-trending pegmatitic sheets and pods. They have sharp but irregular contacts with the host-rocks and are intensely deformed. This deformation can be attributed to repeated brittle reactivation of the nearby Loch Maree Fault during the Phanerozoic (Beacom et al., 2001). The pegmatites are coarsegrained and comprise large K-feldspar augen (up to $5 \mathrm{~cm}$ across) in a strongly foliated matrix of quartz, feldspar, muscovite mica and epidote. In places pervasive alteration is observed along the pegmatite-host-rock contact, where an approximately $10 \mathrm{~cm}$ wide zone in the host amphibolite has been almost entirely replaced by pale green epidote and chlorite.

\subsection{Tarbert terrane and Langavat Belt}

The Tarbert terrane, including the Lewisian Gneiss Complex of North Harris and the Uig Hills Granite Complex, is separated from the Harris Granulite Belt, to the south, by the Langavat Belt (Mason et al., 2004b) (Figs. 1 and 2).

The Archaean gneisses of the Tarbert terrane are stronglybanded, grey quartzo-feldspathic orthogneisses that are locally very heterogeneous and display a range of compositions and textures (Fettes et al., 1992). Granitic pegmatites in the Tarbert terrane generally have sharp but irregular contacts with the hostrock. They tend to form anastomosing networks of veins and thin sheets that cross-cut the gneissose banding at a steep angle. Pegmatite strike directions are locally variable. The pegmatites are very coarse-grained and are composed of quartz, plagioclase and K-feldspar (up to $5 \mathrm{~cm}$ across) with variable amounts of biotite and other accessory minerals, such as pyrite and allanite (up to $2 \mathrm{~cm}$ long) that are concentrated within discrete shear zones in the pegmatite and also along the pegmatite-gneiss contact.

The Uig Hills Granite Complex is a complicated series of granitic veins and sheets, and variably migmatised TTG gneisses within the Lewisian Gneiss Complex (Myers, 1971; Fettes et al., 1992). Granitic pegmatites in the Uig Hills Granite Complex have variable and complex field relationships with the host rock (Fig. 3b). In areas of less migmatisation, pegmatites typically have sharp but irregular contacts with the host gneiss. They occur as steeply dipping, north-west-trending sheets that are commonly parallel to the gneissose banding. The pegmatites comprise very coarse-grained quartz, plagioclase, K-feldspar and biotite with variable amounts of dark, fine-grained accessory minerals, such as magnetite. Pegmatites in highly migmatitic areas have gradational contacts with the host gneisses and also with the larger masses of granodiorite that make up part of the Uig Hills Granite Complex. Pegmatites occur as quartz and K-feldspar-rich pods, lenses and patches within the granodioritic intrusions, with variable amounts of biotite (up to $20 \%$ by volume), magnetite and other dark, finegrained accessory minerals, (e.g. zircon, allanite and titanite). The relationships are clearly displayed around Amhuinnsuidhe, where very coarse, porphyritic granodiorite contains rafts of tonalitic gneiss and abundant sheets of granitic pegmatite up to $1 \mathrm{~m}$ in thickness. The pegmatites have very diffuse contacts with the granodiorite; in places the two lithologies grade into one another. The pegmatites are composed of quartz, plagioclase, K-feldspar and biotite, and contain variable amounts of millimetre-sized accessory minerals that include magnetite and titanite.

The Langavat Belt forms a distinct tectonostratigraphic boundary between the Harris Granulite Belt and the gneisses of the Tarbert Terrane further north (Mason et al., 2004b), and is also considered to represent a major shear zone along which the Harris Granulite Belt was thrust over the Tarbert terrane (Mason et al., 2004a; Mason, 2012). The Langavat Belt is largely composed of amphibolite-facies metasedimentary, metabasic and ultramafic lithologies interspersed with bands of strongly reworked Archaean tonalitic gneiss (Kelly et al., 2008; Mason, 2012). NW-trending granitic pegmatites are widely distributed throughout the Langavat Belt (Mason and Brewer, 2005). They are steeply dipping, commonly emplaced parallel to the host-rock foliation, and locally show evidence of being themselves intensely deformed. The Langavat Belt pegmatites have variable contacts with the host-rock; in some places contacts are very sharp and planar, but elsewhere contacts are gradational and very irregular with evidence of host rock assimilation. The pegmatites typically comprise coarse-grained quartz, essential plagioclase (up to $2 \mathrm{~cm}$ across) and subordinate K-feldspar with variable amounts of biotite, epidote and magnetite.

\subsection{Harris Granulite Belt (HGB)}

The Harris Granulite Belt (Fig. 2) comprises the Leverburgh Belt and the South Harris Igneous Complex (SHIC) (Fettes et al., 1992). The Leverburgh Belt is made up of strongly foliated, NW-SE trending metasedimentary rocks dominated by garnet-bearing, quartzrich gneisses with subordinate pelitic, semi-pelitic and quartzitic lithologies, and lenses of marble, graphitic schist and mafic material (Dearnley, 1963; Dickinson, 1974; Fettes et al., 1992; Baba, 
1998). The SHIC is a zone of coarse-grained meta-igneous rocks (meta-anorthosite, metadiorite, metagabbro and metanorite) (Dearnley, 1963; Witty, 1975; Cliff et al., 1983; Fettes et al., 1992). The whole of the HGB was metamorphosed to granulite facies shortly after its formation at c. $1900 \mathrm{Ma}$ (Cliff et al., 1983; Mason et al., 2004a; Baba et al., 2012). The HGB is thought to extend to a depth of around $7 \mathrm{~km}$ beneath the surface on the basis of geophysical evidence (Westbrook, 1974).

Within the HGB, pegmatites are intruded into both the Leverburgh Belt and the SHIC (Fig. 2). Generally they are large and extend for many hundreds of metres along strike. The grain size of the HGB pegmatites is highly variable, but locally can be extremely coarse, with feldspar crystals up to $1 \mathrm{~m}$ in length. The HGB pegmatites commonly have very sharp, planar contacts with the host rock and are highly discordant to the country-rock foliation, which broadly trends NW-SE (Jehu and Craig, 1927; Dearnley, 1963; Mason, 2015) (Fig. 3c). With the exception of the rare-metal pegmatite at Badcall Bay, the HGB pegmatites differ from pegmatites found in many other Lewisian terranes in that they include some rare-metal pegmatites. These pegmatites are described in detail below.

The main Sletteval pegmatite (Fig. 2) is about $20 \mathrm{~m}$ thick and well exposed in a series of disused quarries, with a parallel branch, about $5 \mathrm{~m}$ thick, to the north of the main intrusion. Both branches are shallow-dipping, and strike between north-east and east. The pegmatite has a very sharp, planar contact with the host metagabbro of the SHIC (Fig. 3c), and in places metagabbroic xenoliths are included within the pegmatite margin. The grain size at Sletteval is extremely variable, ranging from millimetre-sized crystals to metre-long feldspar crystals. The mineral assemblage at Sletteval is relatively simple at the outcrop scale, comprising quartz, plagioclase, K-feldspar, and biotite (individual crystals up to $50 \mathrm{~cm}$ in length) (Fig. 3d), with minor magnetite and rare patches of garnet. The main pegmatite has a c. $1 \mathrm{~m}$ thick, coarse-grained, zoned lower margin which has a sharp contact with the extremely coarsegrained, massive, pegmatitic interior. The centre of the pegmatite is marked by a c. $2 \mathrm{~m}$ wide, quartz-rich core.

Two large pegmatites occur at the summit of Bhoiseabhal (Fig. 2). The more northerly is a steeply dipping, east-westtrending sheet with a sharp, planar contact with the host metagabbro. The pegmatite is massive and unzoned. The grain-size is very coarse with feldspar crystals up to $20 \mathrm{~cm}$ in length being common. The bulk of the pegmatite comprises graphic intergrowths of quartz and alkali feldspar with variable amounts of biotite, magnetite and garnet, the latter rarely occurring together. The main Bhoiseabhal pegmatite is irregular in shape and up to $250 \mathrm{~m}$ across. Contacts with the host metagabbro are sharp but highly irregular, with thin sheets of pegmatite extending into the hostrock and xenoliths of metagabbro included within the pegmatite margins. In xenoliths and close to the pegmatite contact, the metagabbro appears highly altered, with the growth of abundant biotite. Internal zoning in the main pegmatite is poorly developed, although the abundance and grain-size of aluminous minerals such as tourmaline and garnet seem to increase towards the margins of the pegmatite. The bulk of the main pegmatite comprises graphic intergrowths of smoky quartz and alkali feldspar with variable amounts of biotite. At the margins, particularly towards the upper margin, the mineral assemblage includes greenish-grey muscovite mica, magnetite, garnet (up to $1 \mathrm{~cm}$ across) and tourmaline (up to $10 \mathrm{~cm}$ in length). A close association exists between garnet and the greenish-grey muscovite, and they are typically found together in patches (Fig. 3e). No clear contact can be recognised between the biotite-magnetite core and the marginal zones.

Granitic pegmatites in the Leverburgh Belt are exposed at Kyles House (Fig. 2) as a series of steeply dipping north-east trending sheets that cross-cut the strongly foliated host metapelite. The pegmatites have sharp, planar contacts and are typically massive, lacking well-developed internal zonation. They are composed of very coarse-grained, graphic intergrowths of smoky quartz and alkali feldspar with variable amounts of biotite and magnetite. Garnet (up to $1 \mathrm{~cm}$ across) and epidote are present but nowhere abundant. One irregularly-shaped pegmatite at Kyles House has sharp, non-planar contacts with the host metapelite, into which offshoot veins of pegmatite are intruded. The dip and strike of this pegmatite are also quite variable, suggesting it may be a folded sheet. This pegmatite also has a simple mineralogical and textural zonation at its margins, similar to that at the Sletteval main pegmatite. The pegmatite comprises smoky quartz and feldspar with biotite, magnetite (up to $5 \mathrm{~cm}$ across) and garnet (up to $5 \mathrm{~cm}$ across).

The Chaipaval pegmatite is a steeply dipping, NE-SW-trending sheet that can be traced for about $2 \mathrm{~km}$ westwards along strike to the ruins of a medieval chapel at Rubh' an Teampaill. It has a maximum thickness of about $25 \mathrm{~m}$. It forms a distinctive white ridge across the lower slopes of Chaipaval, offset by a series of small faults, and is easily recognised from the village of Northton (Fig. 2) and (Fig. 3f). The pegmatite is very well exposed in a series of small disused quarries at its north-eastern end. It has very sharp, planar contacts with the host metasedimentary rocks of the Leverburgh Belt, rare fragments of which are included within the pegmatite margins. The pegmatite is very coarse grained and massive, lacking any internal zonation. It comprises quartz, plagioclase, rare K-feldspar and greenish-grey muscovite with varying amounts of biotite, garnet and magnetite. Tourmaline and other dark-coloured, fine-grained, accessory minerals such as gahnite, ferrocolumbite, xenotime and monazite are locally abundant, commonly forming discrete patches within the pegmatite. The graphic intergrowth of quartz and alkali feldspar is locally well developed but nowhere common. Muscovite is disseminated throughout the pegmatite but also forms discrete, monomineralic pods that are composed of thick books of mica up to $20 \mathrm{~cm}$ across. Small garnet crystals (between 1 and $2 \mathrm{~mm}$ across) are commonly included within the muscovite books.

Within the HGB, pegmatites are also exposed on the southern side of Roineabhal and at Beinn Tharsuinn. The Roineabhal pegmatite is an ENE-WSW-trending pegmatite that cross-cuts the metasedimentary gneisses of the Leverburgh Belt. It is up to $10 \mathrm{~m}$ wide and typically massive, lacking any internal zonation. The pegmatite comprises quartz, plagioclase, rare K-feldspar and biotite, commonly forming large books up to $10 \mathrm{~cm}$ across. Small (c. $2 \mathrm{~mm}$ ) euhedral garnets are found as inclusions in the biotite. Magnetite crystals up to $1 \mathrm{~cm}$ across also occur in thin stringers within the pegmatite. Two large (up to $10 \mathrm{~m}$ wide), laterally extensive (up to $100 \mathrm{~m}$ in length) pegmatites are exposed on the slopes of Beinn Tharsuinn where they cross-cut the foliated metagabbros of the South Harris Igneous Complex. Contacts with the country rock are irregular but very sharp. The grain size of the pegmatites is locally very variable, ranging from a few millimetres to tens of centimetres. They comprise quartz, plagioclase, K-feldspar and biotite, the latter forming books up to $5 \mathrm{~cm}$ long. Muscovite, magnetite and garnet are also present but nowhere abundant.

\section{Petrography}

Laxfordian pegmatites from all terranes share a number of petrological features. They are typically coarse- to very coarsegrained and inequigranular, commonly with euhedral crystal shapes. Well-developed graphic and granophyric quartz and alkali feldspar intergrowths are locally common. However, pegmatites from the Harris Granulite Belt are characterised by a rather different mineralogy and petrology to those from other terranes 
(i.e. southern mainland, Tarbert terrane and Langavat Belt, and Rhiconich and Assynt terranes).

Rhiconich terrane pegmatites are largely made up of strained quartz plates in a finer-grained matrix of granoblastic quartz, K-feldspar and heavily sericitised plagioclase. Some recrystallisation of quartz is observed, typically along grain boundaries. Chloritised biotite mica occurs as euhedral plates within the granoblastic matrix, commonly with large inclusions of well-formed magnetite. Rare euhedral zircon, titanite and apatite are also associated with mica-rich areas. Pegmatites from the Assynt terrane are rare, but the studied pegmatite from Badcall is mineralogically similar to those from Rhiconich. The feldspar-rich outer zone contains very small (c. $100 \mu \mathrm{m}$ or less), subhedral crystals of ferrocolumbite (Fig. 4a), ferrotantalite and beryl that typically have jagged grain boundaries and pitted surfaces.

Pegmatites from southern mainland areas (i.e. Gairloch and Loch Maree) comprise euhedral plates of sericitised plagioclase and largely unaltered microcline surrounded by a matrix of finegrained, recrystallised quartz (locally forming elongate ribbons), zoisite, epidote and small biotite and muscovite plates. Directional crystal growth and graphic textures are very rarely encountered in southern mainland pegmatites. Accessory minerals include rare euhedral garnet (typically without mineral inclusions), zircon, apatite, titanite, and allanite, the latter often associated with mica. Niobium-tantalum minerals (e.g. aeschynite-(Y)) are extremely rare in these pegmatites and were only found in one sample.

Pegmatites in the Tarbert terrane and Langavat Belt comprise large (up to $2 \mathrm{~cm}$ across) euhedral plates of microcline and sericitised plagioclase set in a finer-grained matrix of recrystallized quartz, commonly with zoisite, epidote and muscovite mica. Graphic textures are absent, but mica and zoisite are aligned in regions of high strain, defining a localised foliation. Coarse-grained patches of chloritised biotite mica are common; they contain interstitial magnetite and euhedral inclusions of apatite, zircon and titanite. Some Tarbert terrane pegmatites also contain euhedral, zoned allanite (Fig. 4b) crystals up to $1 \mathrm{~mm}$ across, which are commonly heavily corroded (in some cases only the original grain shape is preserved). In contrast, some Langavat Belt pegmatites contain metamict xenotime and rare, acicular kasolite (typically infilling void spaces) but allanite has not been recognised.

Granitic pegmatites from the HGB are notably different from those in all other areas. Pegmatites at Sletteval and Beinn Tharsuinn are locally extremely coarse-grained (with feldspar crystals up to $1 \mathrm{~m}$ across), and are characterised by the graphic intergrowth of albitic plagioclase and quartz (Fig. 4c), interspersed with veins and patches of finer-grained recrystallised quartz. Muscovite and biotite-rich patches and veins are common and are typically associated with the development of euhedral epidote and zoisite. Microcline typically occurs as small, irregular blebs within large plagioclase plates, often in conjunction with small (up to $200 \mu \mathrm{m}$ in length) laths of white mica. Less commonly, microcline occurs as euhedral plates within the quartz-plagioclase groundmass. Rare accessory minerals include apatite, magnetite, zircon and titanite. The Sletteval pegmatite also contains very rare, large (up to $2 \mathrm{~cm}$ across), weakly zoned, euhedral garnets that locally contain inclusions of zircon and xenotime. Niobium-tantalum-bearing minerals are not present in these pegmatites, which are therefore termed 'barren' pegmatites.

Pegmatites at Kyles House and Bhoiseabhal show many similarities to Sletteval and Beinn Tharsuinn, but are notably richer in accessory minerals, such as $\mathrm{Nb}-\mathrm{Y}$ oxides (possibly aeschynite$(\mathrm{Y})$ ), zircon and xenotime. They comprise graphic intergrowths of albitic plagioclase and quartz with veins and patches of finegrained recrystallised quartz. Microcline generally takes the form of small, irregular blebs within large plagioclase plates (Fig. 4d), or, less commonly, as euhedral plates within the quartz- plagioclase groundmass. Kyles House pegmatites contain biotite and magnetite and rare muscovite, the muscovite typically occurring as fine-grained flakes within large feldspar plates, or as small aggregates associated with garnet. The central parts of the Bhoiseabhal pegmatite contain biotite and minor magnetite, but appear devoid of muscovite and garnet. Muscovite is mostly found in the marginal parts of the Bhoiseabhal pegmatite, generally occurring as medium to fine-grained patches and stringers wrapped around large, euhedral grains of garnet (up to $1 \mathrm{~cm}$ ) and magnetite (up to $1 \mathrm{~cm}$ across). Inclusion-rich garnets, which are typically confined to the marginal parts of the pegmatites, are common; they contain metamict zircon and xenotime, and a Y-Nboxide, possibly aeschynite-(Y) (Fig. 4e). In samples from the upper part of the Bhoiseabhal pegmatite, schorl tourmaline occurs as rare pods up to $30 \mathrm{~cm}$ across (with individual crystals up to $8 \mathrm{~cm}$ in length) intergrown with small grains of quartz and microcline. Other accessory minerals, associated with garnet and muscovite from the margins of Bhoiseabhal, include metamict monazite, apatite and rare cassiterite.

The Chaipaval rare-metal pegmatite, including the exposure at Rubh' an Teampaill, comprises large, euhedral interlocking plates of quartz, albitic plagioclase and muscovite mica, interspersed with euhedral garnets up to $1 \mathrm{~cm}$ across. Well-developed graphic intergrowths of quartz and plagioclase are also common. Microcline is all but absent in the Chaipaval pegmatite, but, where it does occur it takes the form of small, irregular blebs within large plates of albitic plagioclase. Muscovite mica mostly occurs as euhedral plates, commonly with partially included garnet grains and small inclusions of beryl and gahnite. Interstitial muscovite occurs between closely-packed garnets and infilling fractures within individual garnet grains. Well-formed, inclusion-rich garnets (Fig. 4f) are common and contain euhedral, unzoned ferrocolumbite (Fig. 4g) crystals up to $4 \mathrm{~mm}$ in length and rare, small grains of ferrotantalite. Garnets also contain metamict zircon, rare xenotime and large (up to $500 \mu \mathrm{m}$ across) monazite grains (Fig. 4h). Monazite grains have reaction rims comprising fine-grained apatite and they also contain small inclusions of zircon and apatite.

\section{Analytical methods}

One hundred and eight bulk rock samples were collected from all the major pegmatites within the HGB and from a range of representative pegmatites in all other terranes of the Lewisian Gneiss Complex. Samples are grouped according to the field groupings described above, and grid references are given in Supplemental Table 1. Whole-rock geochemistry was determined from representative pegmatites of all the terranes, allowing comparison across the region. Each sample comprised rock fragments sampled either a large hammer or circular diamond saw. Every effort was made to ensure that these fragments were typical of the pegmatite exposed at surface. Analyses of mineral chemistry focused on pegmatites from the HGB, with the aim of understanding their rare metal mineralogy. Additionally, $\mathrm{U}-\mathrm{Pb}$ geochronology was conducted on a single pegmatite from the HGB.

\subsection{Whole-rock geochemistry}

Bulk-rock samples of approximately $2-4 \mathrm{~kg}$ in weight were collected in order to provide representative analyses of these coarsegrained rocks. These were jaw crushed to a nominal grain size of $5 \mathrm{~mm}$. The crushed sample material was split using a riffle splitter; a $30 \mathrm{~g}$ sub-sample of the riffled material was then milled to a grain size of approximately $32 \mu \mathrm{m}$ using a planetary ball mill fitted with agate milling material. Samples were analysed for 11 major oxides by X-ray fluorescence spectroscopy (XRFS) and for a suite of 43 

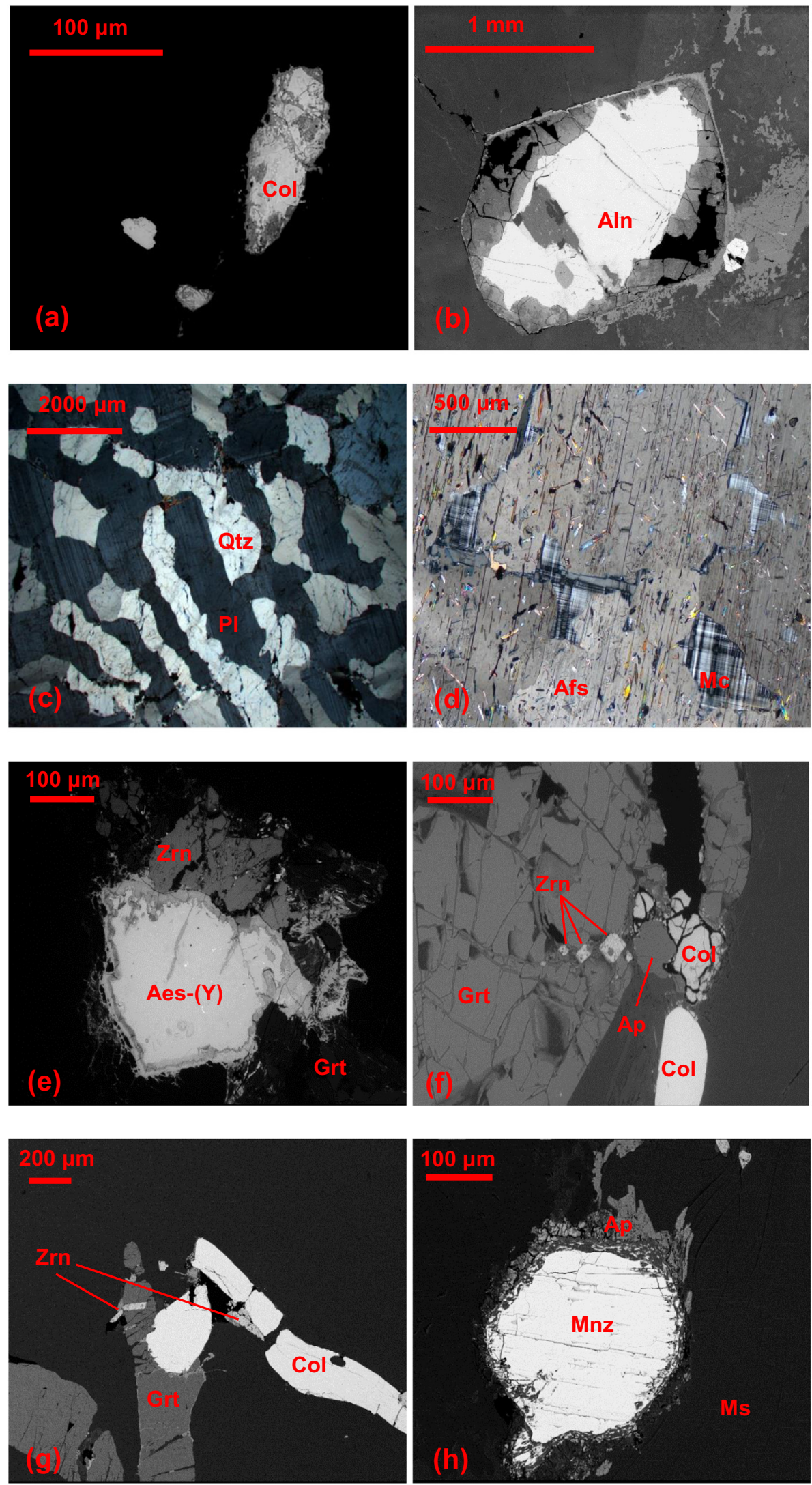

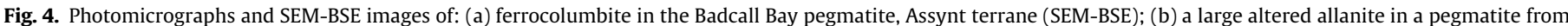

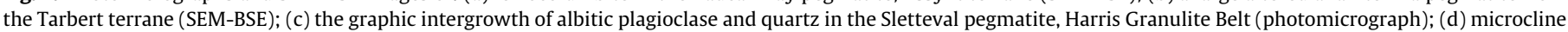

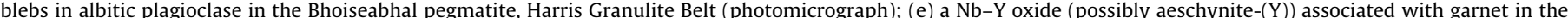

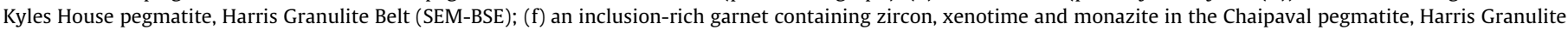

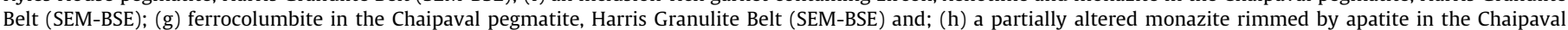
pegmatite, Harris Granulite Belt (SEM-BSE). Mineral abbreviations from Siivola and Schmid (2007), except Aes-(Y) (aeschynite-(Y)). 
trace elements, including the rare earth elements, by inductively coupled plasma mass spectrometry (ICP-MS) at the British Geological Survey (BGS).

\subsection{Inductively coupled plasma mass spectrometry}

Given Li was one of the elements of interest in this study sample decomposition for ICP-MS was achieved by sodium peroxide fusion and mixed acid dissolution, rather than by lithium tetraborate fusion. A $0.2 \mathrm{~g}$ aliquot of powdered sample material was digested in PTFE bombs using a mixture of $\mathrm{HF}, \mathrm{HNO}_{3}$ and $\mathrm{HClO}_{4}$ acid. The PTFE bombs were heated for $5 \mathrm{~h}$ at $100^{\circ} \mathrm{C}$, for $1 \mathrm{~h}$ at $140{ }^{\circ} \mathrm{C}$ and for $6 \mathrm{~h}$ at $190^{\circ} \mathrm{C}$. After cooling, the contents of the bombs were filtered using ashless filter papers. When dried the filter papers were placed in nickel crucibles and ashed at $550{ }^{\circ} \mathrm{C}$ in a furnace, the ash was then fused with $\mathrm{NaOH}$ at $850^{\circ} \mathrm{C}$ for c. 30 min. Finally the fused material was dissolved in a mixed acid solution before analysis. Analysis was performed using an Agilent $7500 \mathrm{cx}$ ICP-MS. A multi-element internal standard containing Sc, Ge, Rh, In, Te and Ir was used during analysis. All sample data are included in Supplemental Table 1.

For the trace elements of interest (i.e. Li, Be, Ga, Rb, Sr, Y, Zr, Nb, $\mathrm{Cs}, \mathrm{Ba}, \mathrm{REE}$, and $\mathrm{Ta}$ ) the relative percentage difference between duplicate sample pairs is typically less than $10 \%$. However, in a small number of duplicate samples the following elements: $\mathrm{Li}$, $\mathrm{Be}, \mathrm{Ba}, \mathrm{REE}$ and Ta, have a slightly higher relative percentage difference of between $10 \%$ and $20 \%$. In a very small number of cases the relative percentage difference, for certain trace elements, is worse than $20 \%$ between duplicate sample pairs. The poorer reproducibility observed in some duplicate samples pairs may be attributed to the small sample size used for digestion (c. $0.2 \mathrm{~g}$ ) and the low concentration of these elements in the samples. Procedural blanks are typically below method limits of detection; however, in some instances $\mathrm{Li}, \mathrm{Be}$ and $\mathrm{Zr}$ are found to be above method limits of detection (LoD). Data for the trace elements of interest in certified reference materials (CRMs), AGV-2 (andesite), BCR-2 (basalt), SDC-1 (mica schist) and SY-3 (syenite) are consistent with accepted values from the GeoRem (Geological and Environmental Reference Materials) online database, with analytical accuracy typically between $90 \%$ and $110 \%$. However, some elements of interest (Be, Ga, Zr, Nb, Sn, Ca, Gd, Dy, Er, Yb, Hf and Ta) are outside this range in SDC-1 and SY-3. This may be due to the refractory nature of the mineral phases hosting these elements and potential for incomplete sample digestion. Data are presented in full in Supplemental Table 1; data for elements consistently below method detection limits have not been included (e.g. B, Ag and Cd). Quality control data, including procedural blanks, LoDs, and analytical accuracy for CRMs are included in full in Supplemental Table 1.

\subsection{X-ray fluorescence spectrometry}

Milled sample material was dried at $105^{\circ} \mathrm{C}$ and then heated to $1050^{\circ} \mathrm{C}$ for one hour before determining loss on ignition (LOI). Fused glass beads, for XRFS analysis, were produced by fusion at $1200^{\circ} \mathrm{C}$. A $0.9 \mathrm{~g}$ aliquot of milled sample was mixed with $9 \mathrm{~g}$ of a pre-fused mixture of lithium tetra-borate and lithium metaborate. The sample and flux was fused at c. $1,200{ }^{\circ} \mathrm{C}$ in Pt-Au crucibles. Analyses were performed using a PANalytical Axios wavelength-dispersive X-ray fluorescence spectrometer, fitted with a $60 \mathrm{kV}$ generator and a $4 \mathrm{~kW}$ rhodium end-window X-ray tube. Data reduction was performed using PANalytical SuperQ 5.1B software. Analytical totals obtained from the instrument, including loss on ignition, are between $98.86 \%$ and $100.89 \%$. All XRFS data and analytical totals are included in Supplemental Table 1.

\subsection{Electron Probe Micro Analysis (EPMA)}

Garnet, K-feldspar, mica and columbite, from the Harris Granulite Belt pegmatites, were analysed using a JEOL JXA 8230 microprobe equipped with five wavelength dispersive (WD) spectrometers, at the University of Leeds Electron Microscopy \& Spectroscopy Centre. Polished sections were cleaned and carbon coated to a thickness of c. $20 \mathrm{~nm}$ prior to analysis. All analyses were performed using a standard accelerating voltage of $15 \mathrm{kv}$, largely at a beam current of $20 \mathrm{nA}$. However, for the analysis of beam sensitive phases (i.e. K-feldspar and mica) a lower beam current of $10 \mathrm{nA}$ was used to reduce beam damage. Analytical totals for the analyses of muscovite are generally low and likely reflect the hydrous nature of mica. Information about calibration standards, crystal assignments, LoD and analytical totals are given in Supplemental Table 4.

\subsection{Laser Ablation Inductively Coupled Plasma Mass Spectrometry (LA-ICP-MS)}

A suite of trace elements, including $\mathrm{Nb}, \mathrm{Ta}, \mathrm{Be}, \mathrm{REE}, \mathrm{Th}$ and $\mathrm{U}$, was determined in garnet and muscovite mica from Bhoiseabhal (SH_14_23b) and Chaipaval (SH_14_18a). After heavy mineral separation forty garnet grains (c. 20 from each sample) were handpicked and mounted in resin. A similar number of mica grains were picked and mounted on glass slides prior to analysis. They were analysed at the British Geological Survey (Nottingham) using a New Wave Research UP193FX excimer laser ablation system coupled to an Agilent 7500 series quadrupole ICP-MS, calibrated using a trace element glass standard (NIST SRM-610). The relative standard deviation for the repeat analysis of a secondary trace element standard (NIST SRM-612) is typically better than $5 \%$ for Ce, Pr, Tm, Lu, Li, Be, Mn, Zn, Ga, Sr, Nb, Sn, Cs, W, Ti, Th and U. And better than $10 \%$ for La, Nd, Sm, Eu, Gd, Tb, Dy, Ho, Er, Yb, Y, Ba, and Ta (Table 5a and b). Data reduction was performed using Iolite software (v2.5). Data (including limits of detection and reference material data) are presented in full in Supplemental Table 5.

\section{6. $U-P b$ geochronology}

In-situ U-(Th)-Pb geochronology was conducted at the NERC Isotope Geosciences Laboratory (Nottingham, UK) Geochronology and Tracers Facility, using a Nu Instruments AttoM single collector sector field inductively coupled plasma mass spectrometer coupled to an ESI NWR193UC laser ablation system. A detailed description of the laboratory's monazite dating method is provided in Mottram et al. (2015). Laser ablation and mass-spectrometer parameters are provided in Supplemental Table 3. Zircons were analysed in an epoxy mount after heavy mineral separation and were imaged with cathodoluminescence to characterise growth zones and crystal defects. Monazite, xenotime and columbite grains were analysed in polished thin-sections. Element maps for $\mathrm{Ce}, \mathrm{La}, \mathrm{U}, \mathrm{Pb}, \mathrm{Th}$, $\mathrm{Y}, \mathrm{Ca}$ and $\mathrm{P}$ in monazite were produced prior to analysis to identify potential growth zoning and/or alteration textures. U-Pb data are presented in full in Supplemental Table 2.

In brief, standard-sample-bracketing was used to normalise $\mathrm{Pb} / \mathrm{Pb}$ and $\mathrm{U} / \mathrm{Pb}$ ratios using well characterised reference materials. These were analysed in batches $(n=3-5)$ between every set of sample analyses $(n=5-10)$. For monazite, $\mathrm{Th} / \mathrm{Pb}$ ages were determined in addition to $\mathrm{U} / \mathrm{Pb}$, and both the ${ }^{208} \mathrm{~Pb} /{ }^{232} \mathrm{Th}$ and ${ }^{206} \mathrm{~Pb} /{ }^{238} \mathrm{U}$ ages were common-lead corrected using the ${ }^{207} \mathrm{~Pb}$-based correction assuming concordance of the samples (e.g. Chew et al., 2011).

Xenotime and columbite lack suitable well characterised reference materials; they were measured using the same analytical procedure as for monazite, but with slight modifications to the normalisation process. A single xenotime of known age was used 
for normalisation of $\mathrm{U} / \mathrm{Pb}$ ratios; since this xenotime has some variable discordance, Stern monazite was used to normalise the $\mathrm{Pb} / \mathrm{Pb}$ ratios. For columbite, no internationally recognised reference material is available. For this reason zircon $(91,500)$ was used to normalise the $\mathrm{U} / \mathrm{Pb}$ ratios, but instead of spot analyses, rasters were employed to minimise inter-element fractionation. NIST614 glass was used to normalise the $\mathrm{Pb} / \mathrm{Pb}$ ratios, according to values of Woodhead and Hergt (2001). With no secondary reference materials analysed, there is no check on accuracy of the method, however, ${ }^{207} \mathrm{~Pb} /{ }^{206} \mathrm{~Pb}$ ages are insensitive to matrix effects, and it is those that are used for interpretation of the mineral crystallisation age.

For monazite, Stern monazite was used to normalise ${ }^{207} \mathrm{~Pb} /{ }^{206} \mathrm{~Pb},{ }^{206} \mathrm{~Pb} /{ }^{238} \mathrm{U}$ and ${ }^{208} \mathrm{~Pb} /{ }^{232} \mathrm{Th}$ ratios, and Manangotry, Moacyr and FC-1 monazites were used as secondary reference materials. For xenotime, Stern monazite was used to normalise the ${ }^{207} \mathrm{~Pb} /{ }^{206} \mathrm{~Pb}$ ratios and $\mathrm{FC}-1$ xenotime was used to normalise the ${ }^{206} \mathrm{~Pb} /{ }^{238} \mathrm{U}$ ratios. For columbite, NIST614 was used to normalise the ${ }^{207} \mathrm{~Pb} /{ }^{206} \mathrm{~Pb}$ ratios and 91,500 zircon was used to normalise the ${ }^{206} \mathrm{~Pb} /{ }^{238} \mathrm{U}$ ratios.

Data processing used the Nu Instruments' time-resolved Attolab software, and an in-house spreadsheet for normalisation and uncertainty propagation. The normalisation process assumes that samples and reference materials behave the same with respect to laser induced elemental fractionation (LIEF). Age uncertainties are quoted at $2 \sigma$, and as age $\pm \alpha / \beta$ (following Horstwood et al. (2016)), where $\alpha$ reflects the analytical uncertainty, and $\beta$ reflects additional propagation of the systematic uncertainties. Systematic uncertainties include decay constants, long-term reproducibility of the laboratory method and uncertainty of the reference values.

\section{Bulk-rock chemistry}

As a result of their coarse grain-size and heterogeneity the major element compositions of individual pegmatites and of the sample population as a whole may vary significantly. Nevertheless, the majority of pegmatite samples from across the Lewisian Gneiss Complex are granitic in composition with $\mathrm{SiO}_{2}>70$ wt.\% (Supplemental Table 1). A small number have lower $\mathrm{SiO}_{2}$ contents (57.74-69.52 wt.\%) and plot in the syenite, diorite and granodiorite fields of a total alkali-silica diagram (Fig. 5). $\mathrm{TiO}_{2}$ and $\mathrm{MgO}$ are typically low ( $<1 \mathrm{wt} . \%$ in all samples) but $\mathrm{CaO}$ and $\mathrm{Fe}_{2} \mathrm{O}_{3}$ are more variable. $\mathrm{CaO}$ ranges between 0.02 and 5.43 wt.\%, with the lowest average concentrations observed in Chaipaval (including samples from the Rubh' an Teampaill exposure) and Bhoiseabhal, and $\mathrm{Fe}_{2} \mathrm{O}_{3}$ ranges between 0.07 and 10.27 wt.\%. Generally $\mathrm{Na}_{2} \mathrm{O}$ is the dominant alkali in all pegmatites except for those from the Tarbert terrane and Langavat Belt, in which $\mathrm{K}_{2} \mathrm{O}>\mathrm{Na}_{2} \mathrm{O}$.

On a Shand index plot (Fig. 6) all samples are peraluminous $(\mathrm{A} / \mathrm{CNK}>1.0)$, with the majority being only mildly peraluminous (A/CNK 1.0-1.1). Two distinct trends are observed on the Shand index plot, one is dominated by pegmatites that contain significant amounts of biotite and magnetite, such as Sletteval, whilst the other is marked by pegmatites that host appreciable amounts of muscovite and garnet, for example Chaipaval. The biotite-magne tite-dominated pegmatites typically have higher values of $\mathrm{A} / \mathrm{NK}$ at any given value of $\mathrm{A} / \mathrm{CNK}$, whereas muscovite-garnet-domina ted pegmatites tend to be more peraluminous, having lower values of $\mathrm{A} / \mathrm{NK}$ at any given value of $\mathrm{A} / \mathrm{CNK}$. However, it is notable that samples from Bhoiseabhal straddle both trends. In the field, the main Bhoiseabhal pegmatite appears crudely composite in nature, with a core of biotite-magnetite pegmatite and marginal zones that contain patches of garnet-muscovite pegmatite. These two zones are distinguished on the A/CNK diagram, with samples from the core plotting with other biotite-magnetite pegmatites, whilst samples from the margins plot with muscovite-garnet pegmatites. Fig. 6 shows that Chaipaval and the marginal parts of Bhoiseabhal lie on a similar trend to the Paleoproterozoic Seinäjoki rare-metal pegmatites in Finland (Mäkitie et al., 2001), the Archaean Tanco pegmatite in Canada (Stilling et al., 2006) and economic raremetal pegmatites (e.g. Greenbushes, Wodgina and Mount Cassiterite) in north-western Australia (Partington et al., 1995; Sweetapple and Collins, 2002).

Trace element patterns for all pegmatites sampled are generally characterised by positive anomalies for $\mathrm{Rb}$, Th and $\mathrm{U}$, and relative depletion in $\mathrm{Ba}$, Sr and $\mathrm{Ti}$ (Fig. 7). The majority of pegmatites are also distinguished by strong negative $\mathrm{Nb}$ and $\mathrm{Ta}$ anomalies and by a relative enrichment of the light (LREE) and middle (MREE) rare earth elements over the heavy rare earth elements (HREE) (Fig 8). However, a small group of pegmatites, including Chaipaval and the marginal parts of Bhoiseabhal in the HGB and the Badcall Bay pegmatite in the Assynt terrane, show a distinct enrichment in $\mathrm{Cs}, \mathrm{Rb}$, $\mathrm{Nb}$ and Ta with strong depletion in $\mathrm{Ba}, \mathrm{Sr}$ and $\mathrm{Ti}$ (Fig. 7). These trends broadly mirror those observed in the Shand index plot in so far as pegmatites with abundant muscovite and garnet tend to

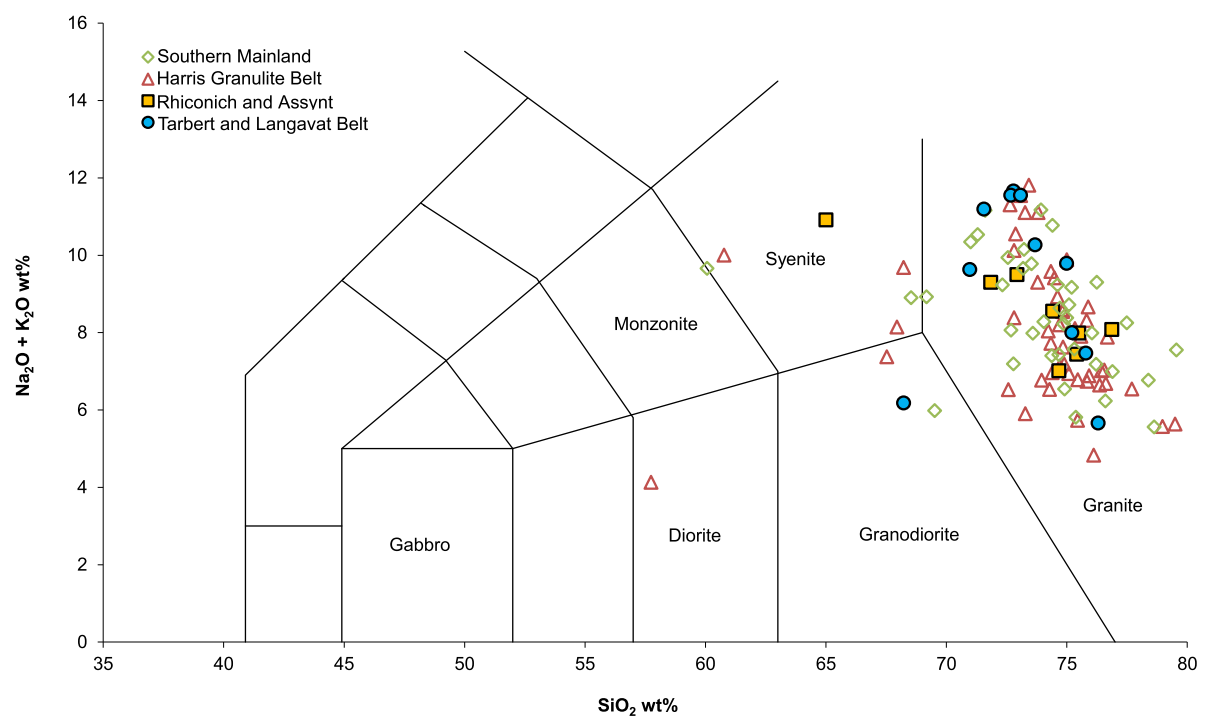

Fig. 5. Total alkali versus silica diagram for all analysed pegmatites. Fields from Gillespie and Styles (1999) 

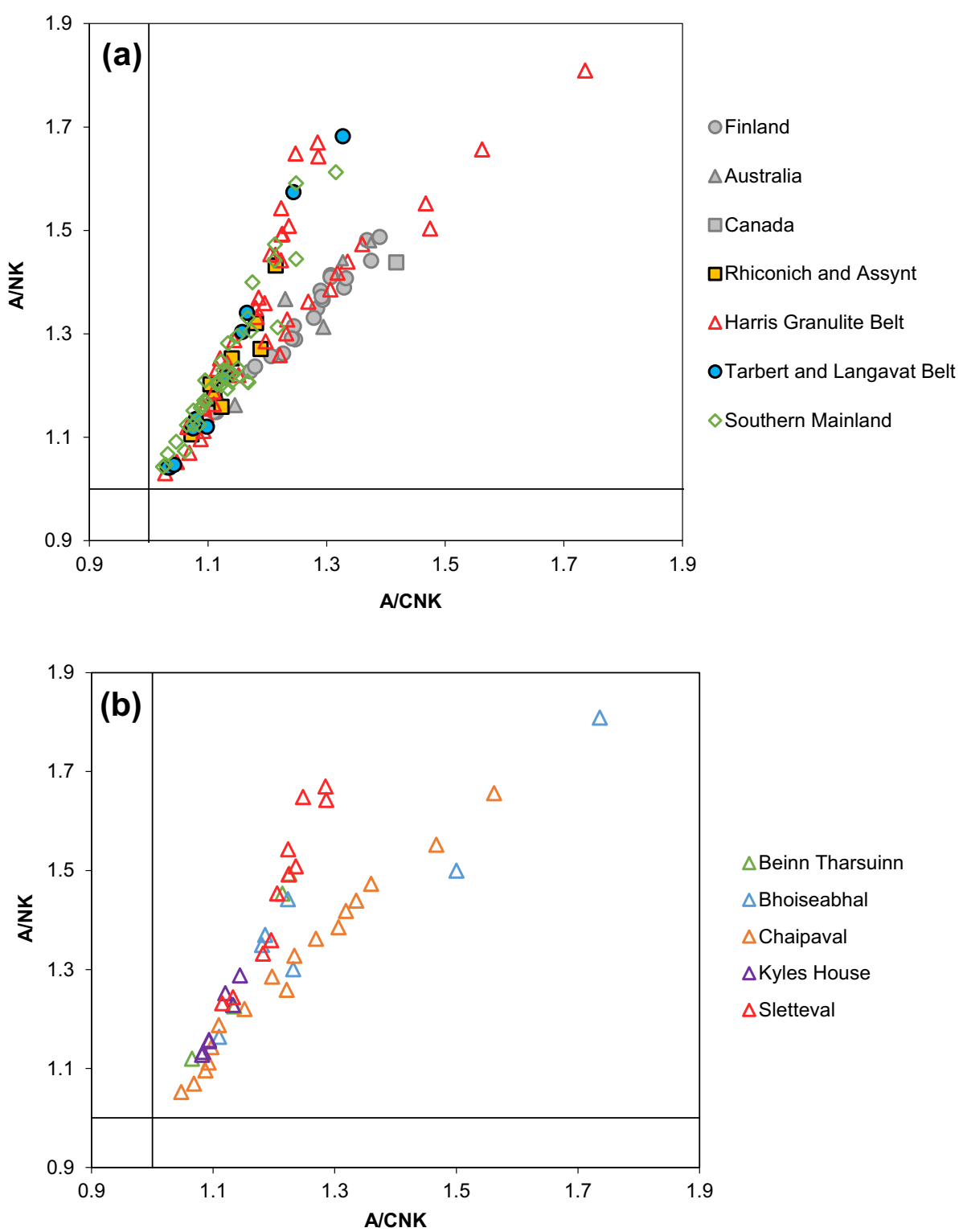

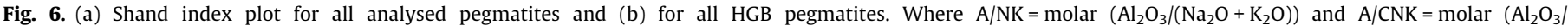

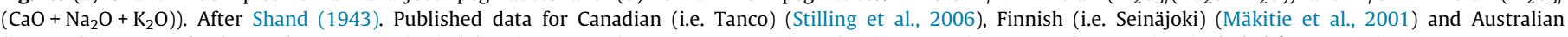
(i.e. Wodgina, Greenbushes and Mount Cassiterite) (Partington et al., 1995; Sweetapple and Collins, 2002) rare-metal pegmatites included for comparison.

contain $\mathrm{Nb}$-Ta-bearing minerals, whereas those dominated by biotite and magnetite typically do not. The presence of abundant muscovite may also explain the enrichment in Cs observed in these pegmatites. These patterns of enrichment and depletion are also consistent with published data (Černý et al., 1985; Černý, 1992; Küster et al., 2009) for rare-metal pegmatites of the LCT family. The pegmatite from the Loch Maree Group (Fig. 7a) also has particularly strong negative $\mathrm{Ba}, \mathrm{Sr}$ and $\mathrm{Ti}$ anomalies, but lacks any notable enrichment in $\mathrm{Cs}, \mathrm{Rb}, \mathrm{Nb}$ and $\mathrm{Ta}$.

Total rare earth element (TREE) concentrations are typically $<100 \mathrm{ppm}$. The highest concentrations (up to $2400 \mathrm{ppm}$ ) are found in allanite-bearing samples from the Tarbert terrane. Rare earth patterns generally show a slight enrichment of the LREE and MREE over the HREE and some have weak positive Eu and Gd anomalies. The Tarbert terrane allanite-bearing pegmatites show a distinct enrichment in the LREE and no Eu anomaly, but do have small positive Gd anomalies. However, pegmatites in the HGB, at Chaipaval, Bhoiseabhal and Kyles House; in the Loch Maree Group; and at Badcall Bay in the Assynt terrane, display strong negative Eu anomalies and no HREE depletion relative to the LREE (Fig. 8). The groupings identified on the Shand index plot (Fig. 6.) are, to some extent, mirrored in the REE plots. Chaipaval and samples from the margins of Bhoiseabhal are both enriched in HREE, due to the abundance of garnet, and display very strong negative Eu anomalies. Interestingly the Beinn Tharsuinn and Kyles House pegmatites seem to represent intermediate compositions, although this is not clearly seen on the Shand index plot. Both of these pegmatites display an enrichment in Nb-Ta and the HREE above that observed in Sletteval, but not to the extent seen in Chaipaval or samples from the margins of Bhoiseabhal. These pegmatites are largely dominated by biotite and magnetite, hence their position on the Shand index plot, but contain enough garnet and muscovite to explain their rare-metal enrichment.

\section{Mineral chemistry}

Various mineralogical features, such as the $\mathrm{K} / \mathrm{Rb}$ ratio of $\mathrm{K}$-feldspar and the $\mathrm{Mn} / \mathrm{Fe}$ ratio of garnets are commonly regarded 

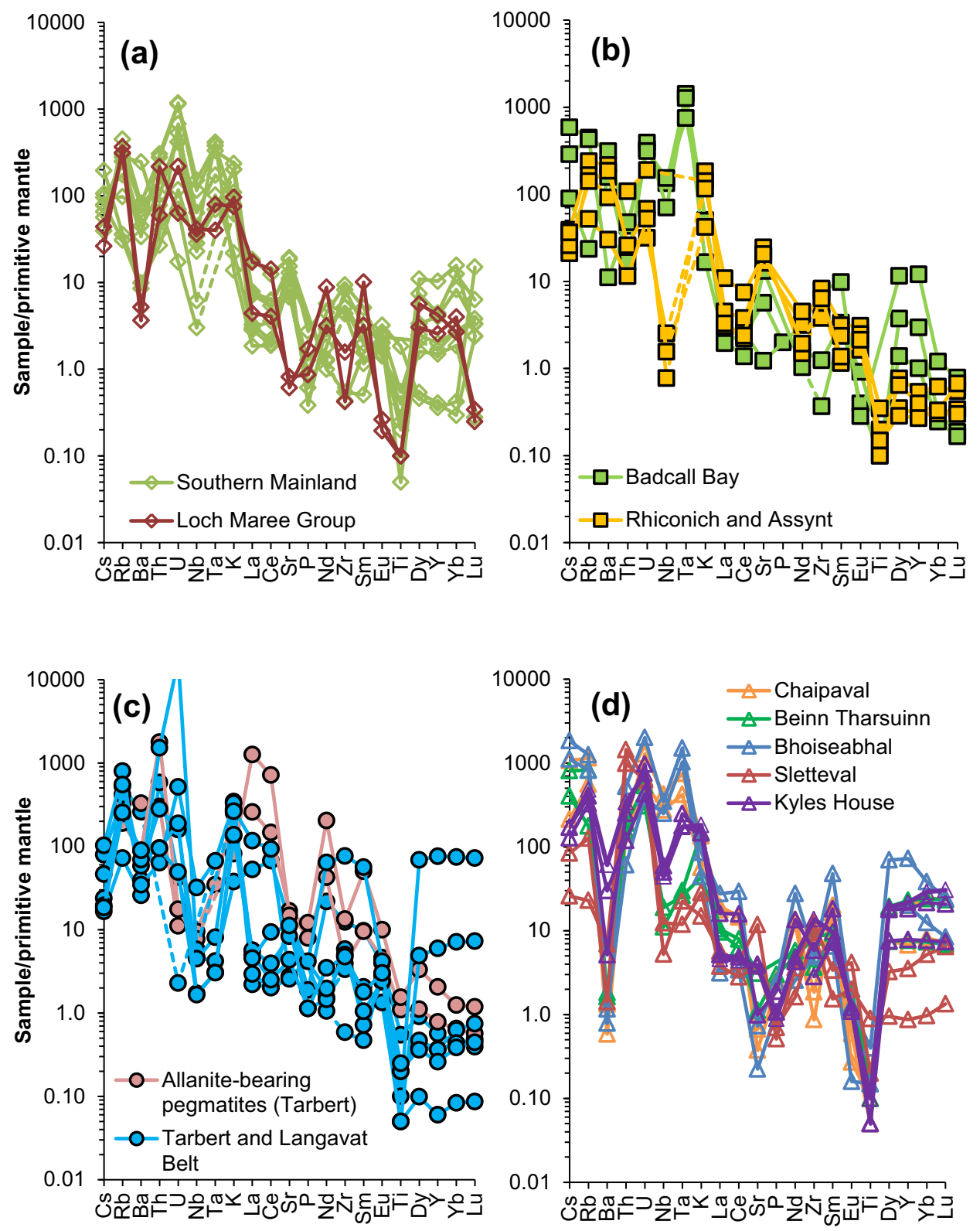

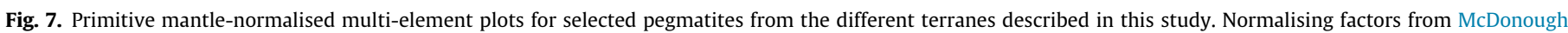
and Sun (1995).

as diagnostic of rare-metal pegmatites. They are interpreted as the result of fractional crystallisation from a parent granite (Černý, 1992; London, 2008; Černý et al., 2012b). However, it seems clear that other processes such as low-degrees of partial melting could produce a similar set of characteristics. Due to their rare-metal enrichment and unusual mineralogy, detailed study of mineral chemistry has focussed on pegmatites from the Harris Granulite Belt. Data for these samples are presented in Supplemental Tables 4 and 5.

\subsection{Garnet}

Garnets from Harris Granulite Belt pegmatites, including two muscovite-garnet (rare-metal) pegmatites (Bhoiseabhal and Chaipaval) and a barren, biotite-magnetite pegmatite (Sletteval) were analysed to: (1) determine how HGB pegmatites compare with economic, rare-metal pegmatites, and (2) understand how peg- matitic garnets differ across the spectrum of HGB pegmatites and also to those found in the country rock.

Garnet from Bhoiseabhal, Sletteval and Chaipaval typically has a compositional range dominated by iron-rich almandine ( Alm $_{48-56}$ ) and slightly subordinate manganese-rich spessartine $\left(\mathrm{Sp}_{35-47}\right)$ components, with combined pyrope (magnesium end-member), andradite (titanium end-member) and grossular (calcium endmember) components generally accounting for less than $10 \mathrm{~mol} . \%$ (Fig. 9 and Table 4a). Such compositions are typical of magmatic garnets in peraluminous granitoids (du Bray, 1988; Dahlquist et al., 2007). Published data of garnet compositions in rare-metal pegmatites are scarce, however garnet in HGB pegmatites is similar in composition to garnet in Canadian (Red Cross Lake; Černý et al. (2012b)) and Norwegian (Froland and Evje-Iveland; (Müller et al., 2012)) rare-metal pegmatites (Fig. 9). The highest $\mathrm{Mn} /(\mathrm{Fe}+\mathrm{Mn}$ ) ratios are observed in Chaipaval garnet with values ranging between 0.45 and 0.49 . Lower ratios are observed in garnet from 

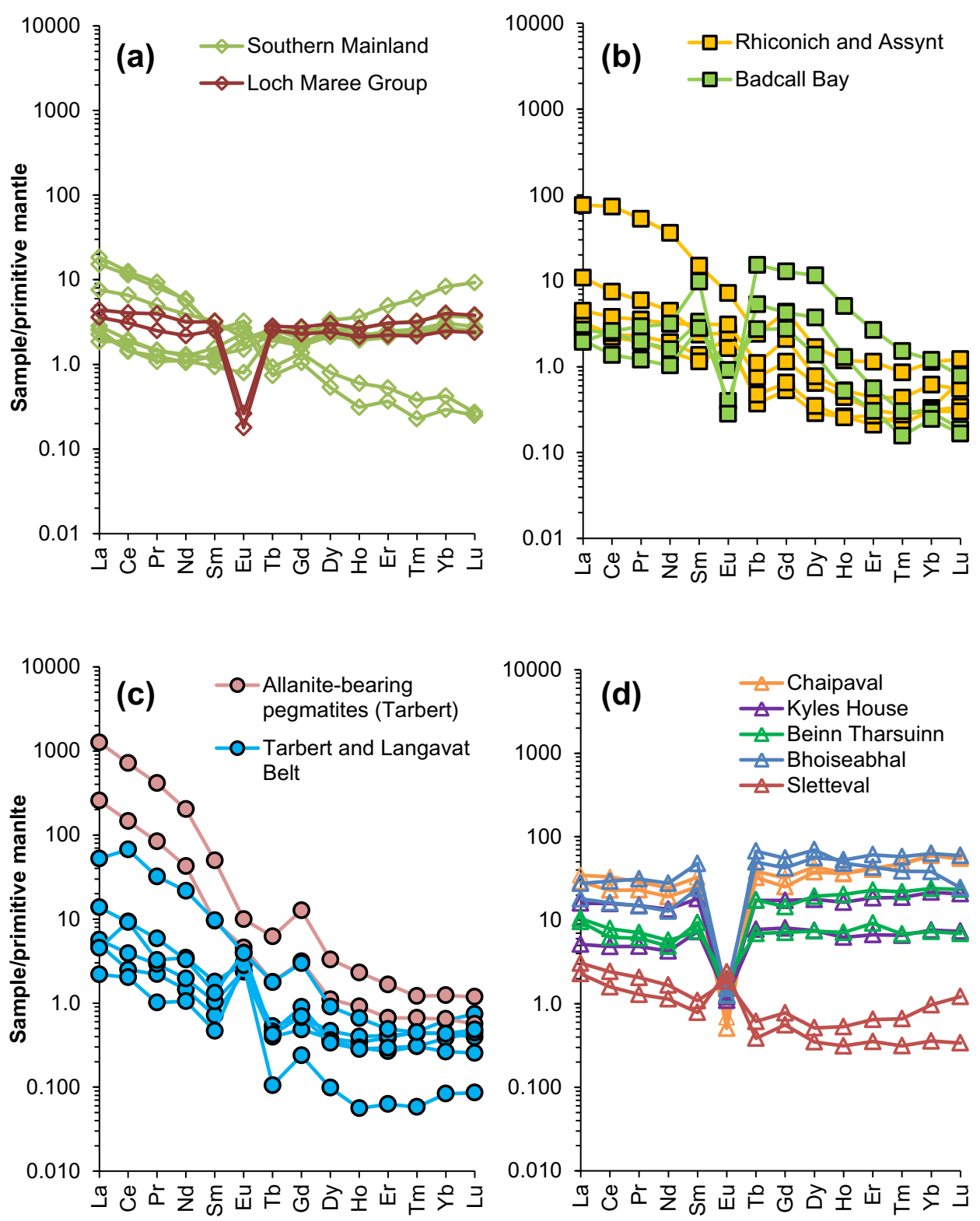

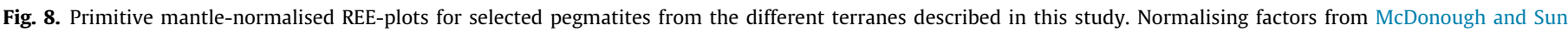
(1995).

Sletteval (0.41-0.46) and from the upper margin of Bhoiseabhal (0.39-0.40) (Table 4a).

It is notable that garnets from HGB pegmatites are generally unzoned. This may suggest rapid crystallisation from high temperature magmas (e.g. $>700^{\circ} \mathrm{C}$ ) (Dahlquist et al., 2007), and that limited in-situ fractionation occurred during pegmatite crystallisation. Garnets from sample HPR-020 (from the margins of Chaipaval), and SH_14_19c (from the core of Chaipaval) have very similar compositions and $\mathrm{Mn} /(\mathrm{Fe}+\mathrm{Mn})$ ratios, further indicating limited in situ fractionation. Notably, the $\mathrm{Mn} /(\mathrm{Fe}+\mathrm{Mn})$ ratios in garnet from the barren Sletteval pegmatite are actually higher than those from Bhoiseabhal. It is interesting that $\mathrm{Mn} /(\mathrm{Fe}+\mathrm{Mn})$ ratios in garnet from the intermediate-type pegmatite at Kyles House are also higher than those from either Chaipaval or Bhoiseabhal - the reason for these anomalous patterns (i.e. the higher Mn contents observed in garnet from a barren pegmatite) remains enigmatic. However, one possible control on these trends is the presence in the rare-metal pegmatites of other mafic minerals that might incorporate $\mathrm{Fe}$ and $\mathrm{Mn}$, such as columbite, biotite, magnetite, and schorl tourmaline. These minerals have been shown to control the Fe and Mn content of melts, and thus the amount of these elements available for inclusion in phases such as garnet (Müller et al., 2012). In contrast to the pegmatites, garnets from the Leverburgh Belt metasedimentary rocks and meta-igneous rocks from the SHIC are typically more iron-rich (Fig. 9) and have much lower $\mathrm{Mn} /(\mathrm{Fe}+\mathrm{Mn}$ ) ratios (Dickinson, 1974; Witty, 1975; Horsley, 1978; Baba, 2003; Hollis et al., 2006). These compositional differences clearly show that pegmatitic garnets have a magmatic origin and are not simply inherited metamorphic garnets.

The pegmatitic garnets are all strongly enriched in $\mathrm{Y}$ and the middle- and heavy rare earth elements relative to the light rare earth elements (Table 5a and Fig. 10), although strong negative Eu anomalies are seen. These are typical patterns for garnet in pegmatites (Müller et al., 2012). Concentrations of the HREE (Gd-Lu) 


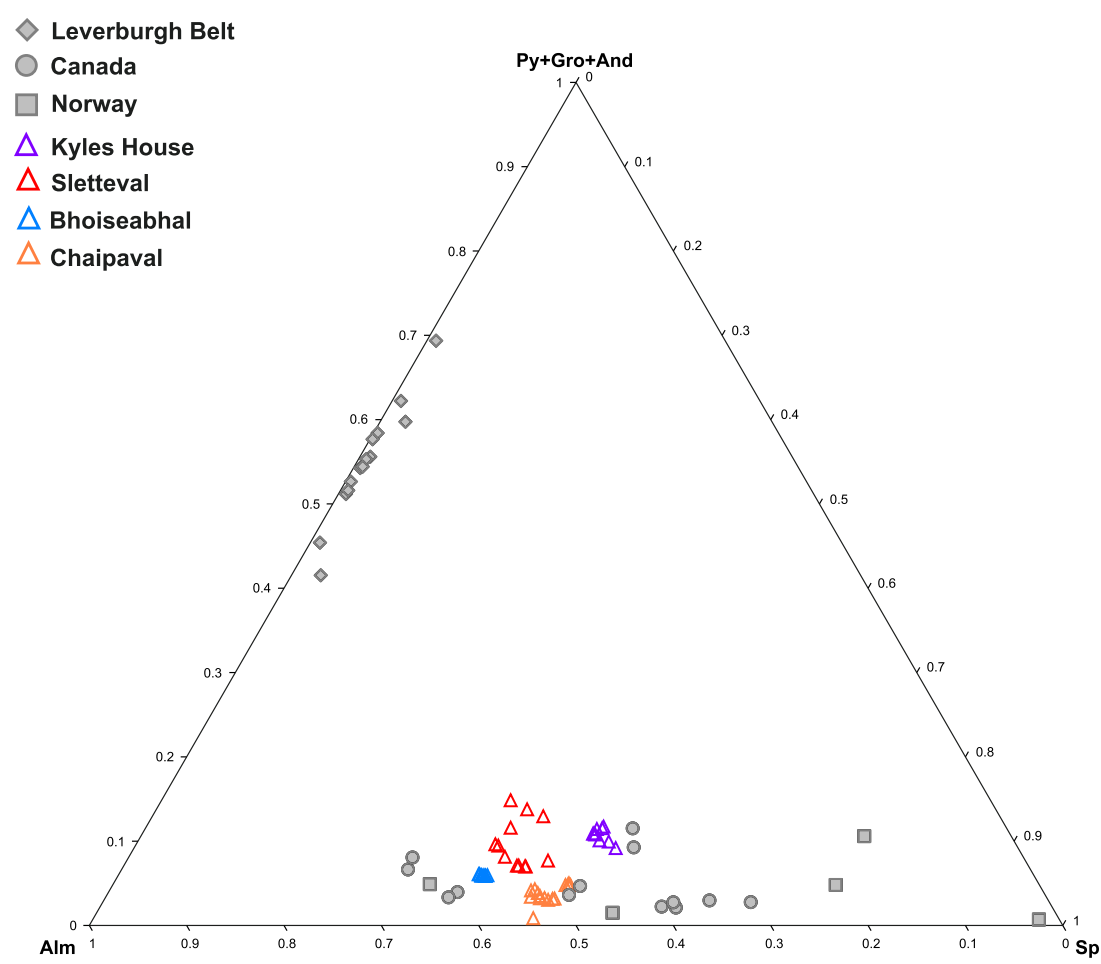

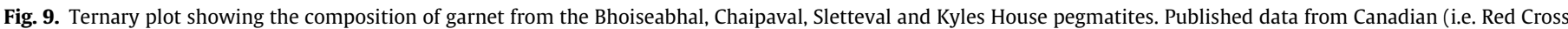

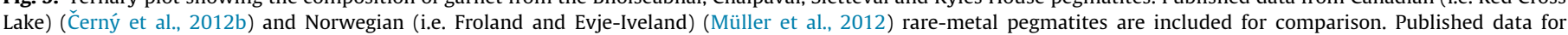

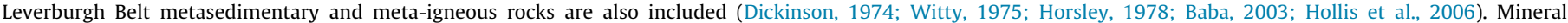
abbreviations from Siivola and Schmid (2007).

plus $\mathrm{Y}$ are typically higher in the Chaipaval pegmatite (ranging between 0.15 and $1.12 \mathrm{wt} . \%$ ) compared to concentrations in the Bhoiseabhal pegmatite (ranging between 0.09 and $0.84 \mathrm{wt} . \%$ ) (Table 5a). There are two distinct populations in the data. Both populations show strong negative $\mathrm{Eu}$ anomalies; however, one population has strong enrichment in all the HREE, whereas the second population is notably lower in $\mathrm{Y}$ and HREE, with a negative slope from $\mathrm{Er}$ to $\mathrm{Lu}$ on a primitive mantle-normalised REE plot (Fig. 10a and b). The two distinct populations occur in both Chaipaval and Bhoiseabhal and may represent cores and rims. However, this cannot be confirmed because analysis was carried out on fragments on grain mounts.

\subsection{Feldspar}

It has been suggested that the $\mathrm{K} / \mathrm{Rb}$ ratio of $\mathrm{K}$-feldspar is an important fractionation indicator in pegmatites (Černý et al., 1985; Küster et al., 2009; Černý et al., 2012b): due to the incompatible behaviour of $\mathrm{Rb}$, the amount of $\mathrm{Rb}$ in $\mathrm{K}$-feldspar increases with increasing fractionation. K-feldspar in fractionated pegmatites also shows a marked depletion in Ba and Sr (Černý et al., 1981; Icenhower and London, 1996). However, it is clear that other factors such as degree of partial melting, source composition, and other crystallising minerals can also control mineral chemistry. K-feldspar from Chaipaval, Bhoiseabhal and Sletteval was analysed for a number of trace elements, including $\mathrm{Rb}, \mathrm{Ba}$ and $\mathrm{Sr}$ to determine: (1) how HGB pegmatites compare with economic, raremetal pegmatites, and (2) to investigate the trace element variations between pegmatites.

Major element concentrations in K-feldspar from Sletteval, and K-feldspar blebs in Chaipaval and Bhoiseabhal, expressed as endmember compositions, are generally uniform and have a narrow compositional range between $\mathrm{Or}_{93.8}$ and $\mathrm{Or}_{95.5}$, with a maximum albite content of $6 \%$. No notable zonation was recognised in the analysed K-feldspars. With the exception of $\mathrm{Rb}$ all other trace elements (e.g. Ba, $\mathrm{Cs}, \mathrm{F}$ and $\mathrm{Cl}$ ) are typically below microprobe detection limits. The depletion of $\mathrm{Ba}, \mathrm{Sr}$ and to some extent $\mathrm{Cs}$ in $\mathrm{K}$-feldspar is well documented in rare-metal pegmatites (Černý et al., 1985). K-feldspar from the margins of Bhoiseabhal is most enriched in rubidium (0.13-0.20 wt.\% $\mathrm{Rb}_{2} \mathrm{O}$ ), followed by Chaipaval (0.06-0.17 wt.\% $\mathrm{Rb}_{2} \mathrm{O}$ ) and Sletteval (up to 0.09 wt.\% $\mathrm{Rb}_{2} \mathrm{O}$ ). The $\mathrm{K} /$ $\mathrm{Rb}$ ratio of K-feldspar from Bhoiseabhal varies between 74.29 and 115 , and between 81.46 and 232 in K-feldspar from Chaipaval. The $\mathrm{K} / \mathrm{Rb}$ ratio of $\mathrm{K}$-feldspar from Sletteval is notably higher with values ranging between 160 and 249 (Fig. 11 and Table 4b). These $\mathrm{K} / \mathrm{Rb}$ ratios overlap with those for rare-metal pegmatites in Finland (Lappalainen and Neuvonen, 1968); Fig. 11) but do not attain the very low values of the economically important Canadian raremetal pegmatites (Černý and Macek, 1972; Černý, 1989; Černý et al., 2012b); Fig. 11). Rb typically behaves incompatibly in peraluminous melts, but is partitioned into micas when they begin to crystallise (Icenhower and London, 1995, 1996). Lower contents of $\mathrm{Rb}$ in feldspars from barren pegmatites most likely represent earlier partitioning of $\mathrm{Rb}$ into biotite.

The compositional range of plagioclase in Sletteval, Chaipaval and Bhoiseabhal is dominated by albite $\left(A_{90.1}\right.$ and $\left.A_{99.2}\right) . R b$, $\mathrm{Cs}, \mathrm{F}$ and $\mathrm{Cl}$ are at levels below method detection limits (Table $4 \mathrm{~b}$ ). Feldspar in the HGB pegmatites is typically unzoned, again suggesting that in-situ fractionation during crystallisation was limited.

\subsection{Muscovite mica}

The trace element composition of muscovite mica has been reported to be another useful indicator of the extent of fractionation in rare-metal pegmatites (Tischendorf et al., 2001; London, 2008). In highly fractionated pegmatites the concentrations of $\mathrm{Rb}$, $\mathrm{Cs}, \mathrm{Li}, \mathrm{Mn}, \mathrm{Ga}, \mathrm{Tl}, \mathrm{Sn}$ and Ta in muscovite mica increase, whilst 

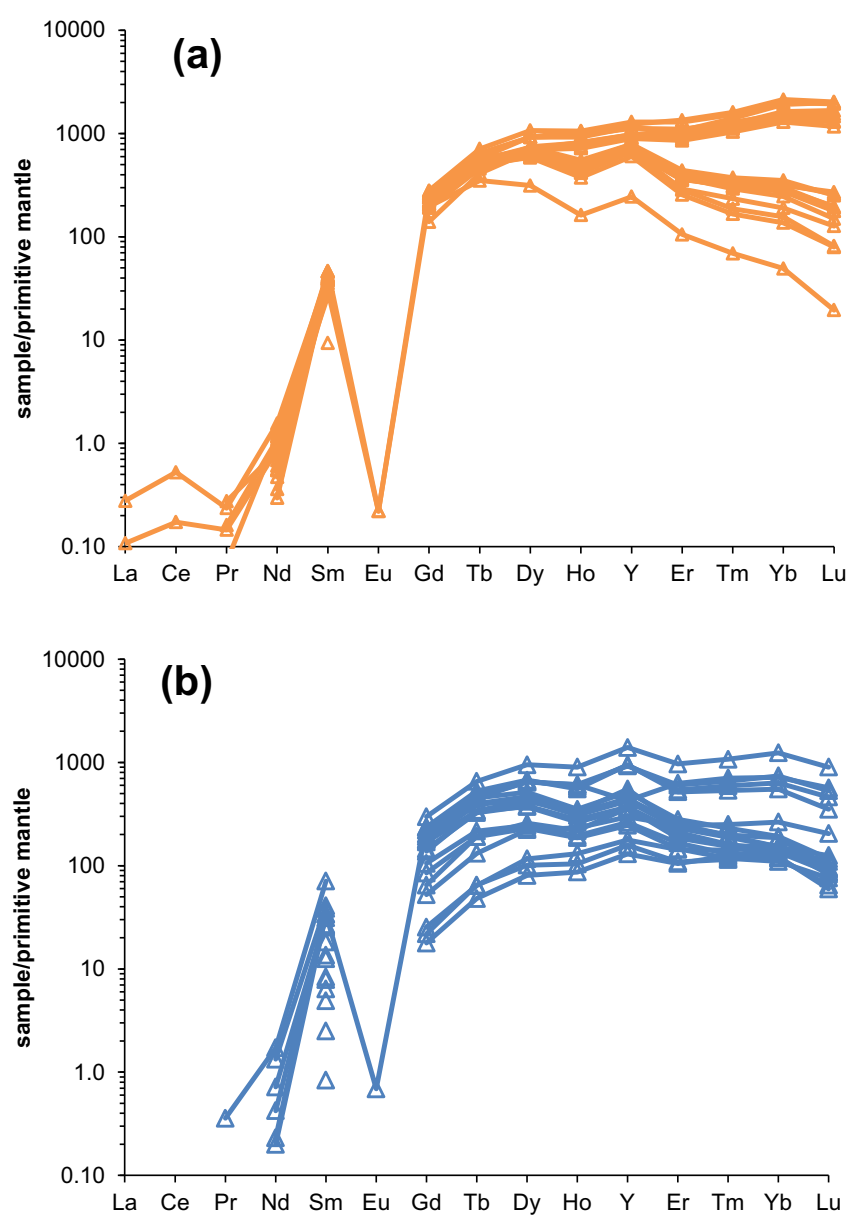

Fig. 10. The distribution of REE and $Y$ in garnet from the (a) Chaipaval and (b) Bhoiseabhal pegmatites, Harris Granulite Belt. Normalising factors from McDonough and Sun (1995).

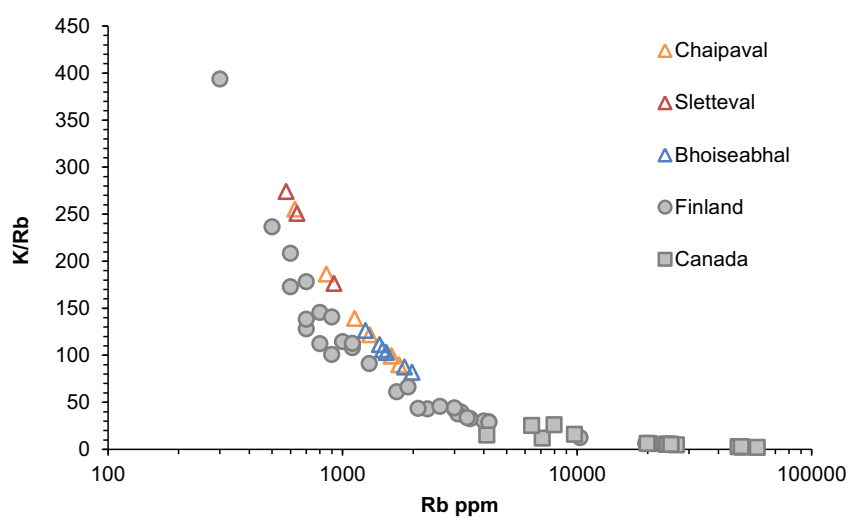

Fig. 11. $\mathrm{K} / \mathrm{Rb}$ ratio versus $\mathrm{Rb}(\mathrm{ppm})$ in $\mathrm{K}$-feldspar from the Chaipaval, Bhoiseabhal and Sletteval pegmatites, Harris Granulite Belt. Published data from Canadian (i.e. Red Cross Lake, Tanco and Lac du Bonnet) (Černý and Macek, 1972; Černý, 1989; Černý et al., 2012b) and Finnish (i.e. Kaatiala and Rosendal) (Lappalainen and Neuvonen, 1968) rare-metal pegmatites are included for comparison.

$\mathrm{K} / \mathrm{Rb}, \mathrm{K} / \mathrm{Cs}, \mathrm{K} / \mathrm{Tl}, \mathrm{Fe} / \mathrm{Mn}$ and $\mathrm{Al} / \mathrm{Ga}$ ratios show a concomitant decrease. The Ta and Cs content of muscovite mica have also been used as an exploration tool to identify the potential for Ta-Nb mineralisation in pegmatites (Selway et al., 2005). Pegmatites containing muscovite with a Ta concentration greater than $65 \mathrm{ppm}$ and a Cs concentration above $500 \mathrm{ppm}$ are highly likely to contain Ta-Nb mineralisation (Selway et al., 2005). Muscovite micas from
Chaipaval and Bhoiseabhal pegmatites were analysed for comparison with those in highly fractionated pegmatites that have potential for Nb-Ta mineralisation.

Mica from Chaipaval and Bhoiseabhal is muscovitic in composition, being rich in $\mathrm{Si}, \mathrm{Al}$ and $\mathrm{K}$, but low in $\mathrm{Mg}$ and $\mathrm{Fe}$. Rb contents in muscovite from Chaipaval range between 0.17 and $0.27 \mathrm{wt} . \% \mathrm{Rb}_{2} \mathrm{O}$, lower concentrations are typically observed in muscovite from Bhoiseabhal (between 0.09 and 0.20 wt.\% $\mathrm{Rb}_{2} \mathrm{O}$ ). $\mathrm{K} / \mathrm{Rb}$ ratios are generally lower in muscovite from Chaipaval, ranging between 38.39 and 60.98, compared to muscovite from Bhoiseabhal $(\mathrm{K} / \mathrm{Rb}$ ratios between 53.68 and 118) (Fig. 12). However, Chaipaval muscovites do not attain the very low $\mathrm{K} / \mathrm{Rb}$ ratios seen in the Canadian rare-metal pegmatites (Černý et al., 2012b). The halogens ( $\mathrm{F}$ and $\mathrm{Cl}$ ) are notably enriched in muscovite from Chaipaval (up to $0.64 \mathrm{wt} . \%$ $\mathrm{F}$ and 0.02 wt.\% $\mathrm{Cl}$ ). Halogen concentrations in muscovite from Bhoiseabhal are variable but typically lower than Chaipaval (maximum 0.30 wt.\% $\mathrm{F}$ and $<0.01 \mathrm{wt} . \% \mathrm{Cl}$ ) (Table 4c).

Muscovite from Chaipaval and Bhoiseabhal is enriched in a number of trace elements (Table 5b), including $\mathrm{Li}$ (up to $671 \mathrm{ppm}$ ), Be (up to $28.4 \mathrm{ppm}$ ), Ga (up to $224 \mathrm{ppm}$ ), Mn (up to $1020 \mathrm{ppm}$ ), Zn (up to $237 \mathrm{ppm}$ ), Nb (up to $782 \mathrm{ppm}$ ), Sn (up to $101 \mathrm{ppm}$ ), Cs (up to $338 \mathrm{ppm}$ ), Ta (up to $148 \mathrm{ppm}$ ), W (up to $55 \mathrm{ppm}$ ) and $\mathrm{Tl}$ (up to $17.1 \mathrm{ppm}$ ) but is relatively depleted in $\mathrm{Ba}$, Sr, REE, Th and U. These patterns of enrichment and depletion could indicate the presence of micro-inclusions within the muscovite crystals; however, the consistency of data derived from individual crystals $(n=20)$ suggest otherwise.

Bhoiseabhal muscovite is richer in Be, Mn, $\mathrm{Nb}$, Ta and $\mathrm{W}$ than that from Chaipaval. These differences can be attributed to the presence of accessory minerals such as beryl and columbite in Chaipaval, which have preferentially taken up these elements, whereas in Bhoiseabhal muscovite represents an important host.

\subsection{Columbite-tantalite}

The composition of columbite-tantalite minerals and the presence of other complex $\mathrm{Nb}-\mathrm{Ta}-\mathrm{Sn}$-Ti oxides have been used by other workers to assess the degree of fractionation in raremetal pegmatites, in that the $\mathrm{Fe} / \mathrm{Mn}$ and $\mathrm{Nb} / \mathrm{Ta}$ ratios of columbite-tantalite minerals typically decrease with increasing fractionation (Černý et al., 1985; Tindle and Breaks, 1998; London, 2008; Küster et al., 2009). Černý et al. (1985) describe the transition between primitive (i.e. least fractionated) and highly-evolved pegmatites in terms of their Nb-Ta mineralogy. Primitive pegmatites are generally marked by the presence of

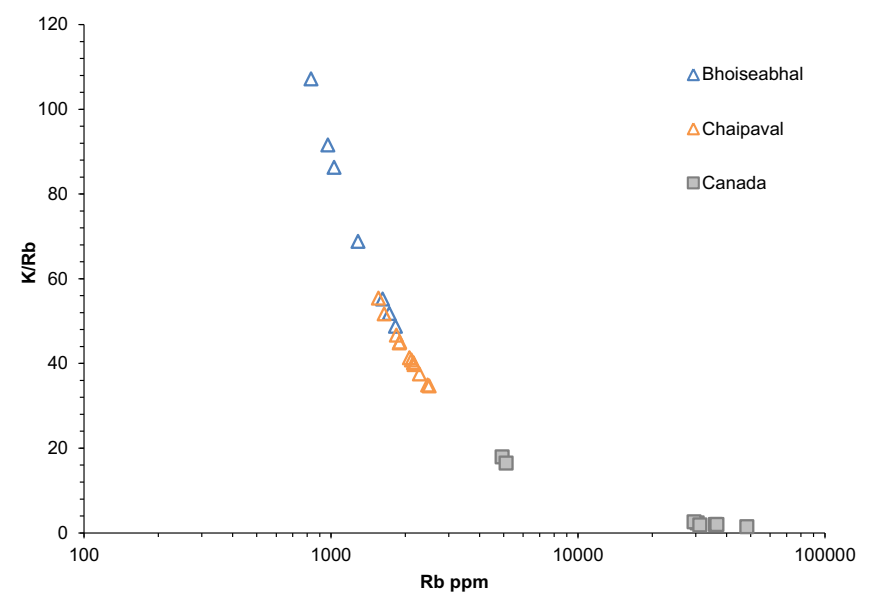

Fig. 12. $\mathrm{K} / \mathrm{Rb}$ ratio versus $\mathrm{Rb}(\mathrm{ppm})$ in muscovite from the Chaipaval and Bhoiseabhal pegmatites, Harris Granulite Belt. Published data from Canadian (i.e. Red Cross Lake) (Černý et al., 2012b) rare-metal pegmatites are included for comparison. 
aeschynite and euxenite-type minerals. Rare element class pegmatites typically contain columbite-tantalite minerals and sometimes microlite. The most evolved pegmatites contain oxides dominated by Ta, such as ixiolite and wodginite.

In the HGB, columbite-tantalite minerals are most abundant in the Chaipaval pegmatite, whereas in Bhoiseabhal and Kyles House the principal $\mathrm{Nb}-\mathrm{Ta}$ host is a $\mathrm{Y}-\mathrm{Nb}$-oxide, possibly aeschynite-(Y). EPMA analysis of columbite from Chaipaval suggests it is the ironrich end-member, ferrocolumbite. Compositionally it is dominated by $\mathrm{Nb}$ and $\mathrm{Fe}$, containing between 69.12 and $71.31 \mathrm{wt} . \% \mathrm{Nb}_{2} \mathrm{O}_{5}$ and between 12.56 and $13.07 \mathrm{wt} . \% \mathrm{FeO}$. It also contains significant Ta (up to 7.39 wt.\% $\mathrm{Ta}_{2} \mathrm{O}_{5}$ ) and $\mathrm{Mn}$ (up to $6.55 \mathrm{wt} . \% \mathrm{MnO}$ ), and minor amounts of $\mathrm{Ti}$ (up to $0.95 \mathrm{wt} . \% \mathrm{TiO}_{2}$ ), $\mathrm{W}$ (up to $0.43 \mathrm{wt} . \% \mathrm{WO}_{3}$ ) and $\mathrm{Y}$ (up to 0.18 wt.\% $\mathrm{Y}_{2} \mathrm{O}_{3}$ ) (Table $4 \mathrm{~d}$ ). Chaipaval ferrocolumbite typically has an $\mathrm{Fe} / \mathrm{Mn}$ ratio between 1.93 and 2.05 and a $\mathrm{Nb} / \mathrm{Ta}$ ratio between 6.83 and 8.53. The variation in $\mathrm{Nb}-\mathrm{Ta}$ minerals observed in different pegmatites is worthy of note. In barren pegmatites (i.e. Sletteval) Nb-Ta-bearing minerals are almost entirely absent, whilst $\mathrm{Nb}$ in intermediate-type pegmatites is dominantly hosted by $\mathrm{Nb}-\mathrm{Y}$ oxides such as aeschynite-(Y). Whereas $\mathrm{Nb}$ and $\mathrm{Ta}$ in rare-metal pegmatites (i.e. Chaipaval) is hosted almost exclusively by columbite-tantalite minerals.

\subsection{Mineral chemistry summary}

Mineral chemistry highlights the variation within the HGB pegmatites. In general, the trends in mineral chemistry reflect the trends in whole-rock chemistry, specifically the variations in peraluminosity which appear to control the mineralogy. Sletteval, a simple biotite-magnetite pegmatite, which lacks any Nb-Ta minerals, has the highest $\mathrm{K} / \mathrm{Rb}$ ratios in feldspar and relatively low $\mathrm{Mn} /(\mathrm{Fe}+\mathrm{Mn})$ ratios in garnet. The marginal zone of Bhoiseabhal, which contains $\mathrm{Y}-\mathrm{Nb}$ oxides rather than columbite-tantalite and muscovite, has low $\mathrm{K} / \mathrm{Rb}$ ratios in feldspar but higher $\mathrm{K} / \mathrm{Rb}$ ratios in muscovite, likely indicating some partitioning of $\mathrm{Rb}$ into biotite. Chaipaval has the most 'fractionated' mineral compositions of the HGB pegmatites; it contains columbite-tantalite minerals and muscovite rather than biotite, has high $\mathrm{Mn} /(\mathrm{Fe}+\mathrm{Mn})$ in garnet, and has relatively low $\mathrm{K} / \mathrm{Rb}$ in both alkali feldspar and muscovite. Overall the mineral chemistry indicates that within the HGB there is a variation in pegmatite composition from 'less-peraluminous' barren pegmatites to more 'highly-peraluminous' rare-metal pegmatites.

\section{Geochronology of rare-metal pegmatites}

Whole-rock and mineral chemistry indicate that the HGB contains some rare-metal pegmatites that are distinctly compositionally different to the pegmatites elsewhere in the Lewisian Gneiss Complex. This compositional difference could potentially indicate a different formation age for these pegmatites, which have not previously been dated by modern methods. To test this, U-Pb geochronological analysis has been carried out on samples from the HGB pegmatites.

\subsection{Zircon}

Zircon grains were extracted from two pegmatites, Bhoiseabhal and Sletteval, and imaged in thin section from the Chaipaval pegmatite. All grains showed distinctly low-luminescence, with occasional relict oscillatory zoning, but generally no or highly disturbed zoning patterns. Th-rich inclusions are present in some grains. Those zircons analysed had very high uranium contents $(>5000 \mathrm{ppm})$, and the low-luminescence in all grains is thus considered to be the result of a high degree of radiation damage.
$\mathrm{U}-\mathrm{Pb}$ analyses were attempted on several grains, but all data were scattered and highly discordant, and thus are not considered further.

\subsection{Monazite in sample HPR-020 (Chaipaval pegmatite, HBG)}

Monazite in HPR-020 comprises large (up to $700 \mu \mathrm{m}$ across) euhedral grains commonly included in primary garnet or muscovite mica. SEM-BSE images show that monazite grains have thin reaction rims but largely intact cores (Fig. 4h). SEM-EDS element maps for $\mathrm{Ce}, \mathrm{La}, \mathrm{U}, \mathrm{Pb}, \mathrm{Th}, \mathrm{Y}, \mathrm{Ca}$ and $\mathrm{P}$ confirm that the rim regions have been altered to apatite, and that core regions are relatively homogeneous. The zone of reaction is most extensive around monazite hosted by muscovite mica.

Thirty-seven analyses were made on four large monazite grains. One monazite produced highly scattered $\mathrm{Th}-\mathrm{Pb}$ and some discordant $\mathrm{U}-\mathrm{Pb}$ ages, implying that the isotopic systems have been disturbed, presumably during a later event. Excluding two slightly older ${ }^{207} \mathrm{~Pb} /{ }^{206} \mathrm{~Pb}$ ages that relate to this altered grain, all of the data form a regression on a Wetherill plot with an upper intercept ${ }^{207} \mathrm{~Pb} /{ }^{206} \mathrm{~Pb}$ age of $1712 \pm 9 / 36 \mathrm{Ma}(2 \sigma, \quad \mathrm{MSWD}=2.3, n=35)$ (Fig. 13). The MSWD of 2.3 implies some geological or analytical scatter, and in this case is probably related to some disturbance of the grains during later alteration.

\subsection{Xenotime in sample HPR-020 (Chaipaval pegmatite, HBG)}

One xenotime grain was analysed adjacent to a zircon grain and one of the analysed monazite grains. Five analyses were made on this grain, and all exhibit slight discordance. The weighted mean ${ }^{207} \mathrm{~Pb} /{ }^{206} \mathrm{~Pb}$ age is $1517 \pm 17 / 35 \mathrm{Ma}(2 \sigma, \quad \mathrm{MSWD}=0.88, n=5)$ (Fig. 13).

\subsection{Columbite in sample HPR-020 (Chaipaval pegmatite, $H B G$ )}

Columbite in HPR-020 comprises large (up to $1000 \mu \mathrm{m}$ in length) euhedral grains commonly included in the quartzfeldspar matrix, or locally found partially included in garnet (Fig. 4g). SEM-BSE imaging and EPMA show columbite grains are homogeneous and lack internal zonation.

Fourteen analyses were made on two large columbite grains. Three analyses exhibited slightly older ${ }^{207} \mathrm{~Pb} /{ }^{206} \mathrm{~Pb}$ ages than a distinct main population, but exhibited higher common lead concentrations. Excluding these three analyses, the remaining eleven give a weighted mean ${ }^{207} \mathrm{~Pb} /{ }^{206} \mathrm{~Pb}$ age of $1690 \pm 19 / 39 \mathrm{Ma}$ (95\% conf., MSWD = 11.4, $n=11$ ) (Fig. 13).

\section{Discussion}

\subsection{Age of the pegmatites}

Monazite and columbite grains from the Chaipaval pegmatite yield low-precision, overlapping ages of $1712 \pm 36 \mathrm{Ma}$ and $1690 \pm 39 \mathrm{Ma}$, respectively. The age of crystallisation of this pegmatite is thus interpreted to be c. $1700 \mathrm{Ma}$. Interestingly, dated xenotime gave a younger age of c. $1520 \mathrm{Ma}$. The xenotime grain in question is texturally related to the rim of an embayed monazite grain found within a crack in a garnet. Zircon is also found adjacent to the xenotime and monazite grains. The xenotime age is interpreted as recording a younger alteration event affecting the monazite and precipitating xenotime, (Hetherington and Harlov, 2008; Harlov and Hetherington, 2010). These fluid-induced reactions resulted in new xenotime growth and the observed isotopic disturbance of monazite. Other monazite grains within muscovite and fractured garnet feature reaction rims; however, their isotopic 

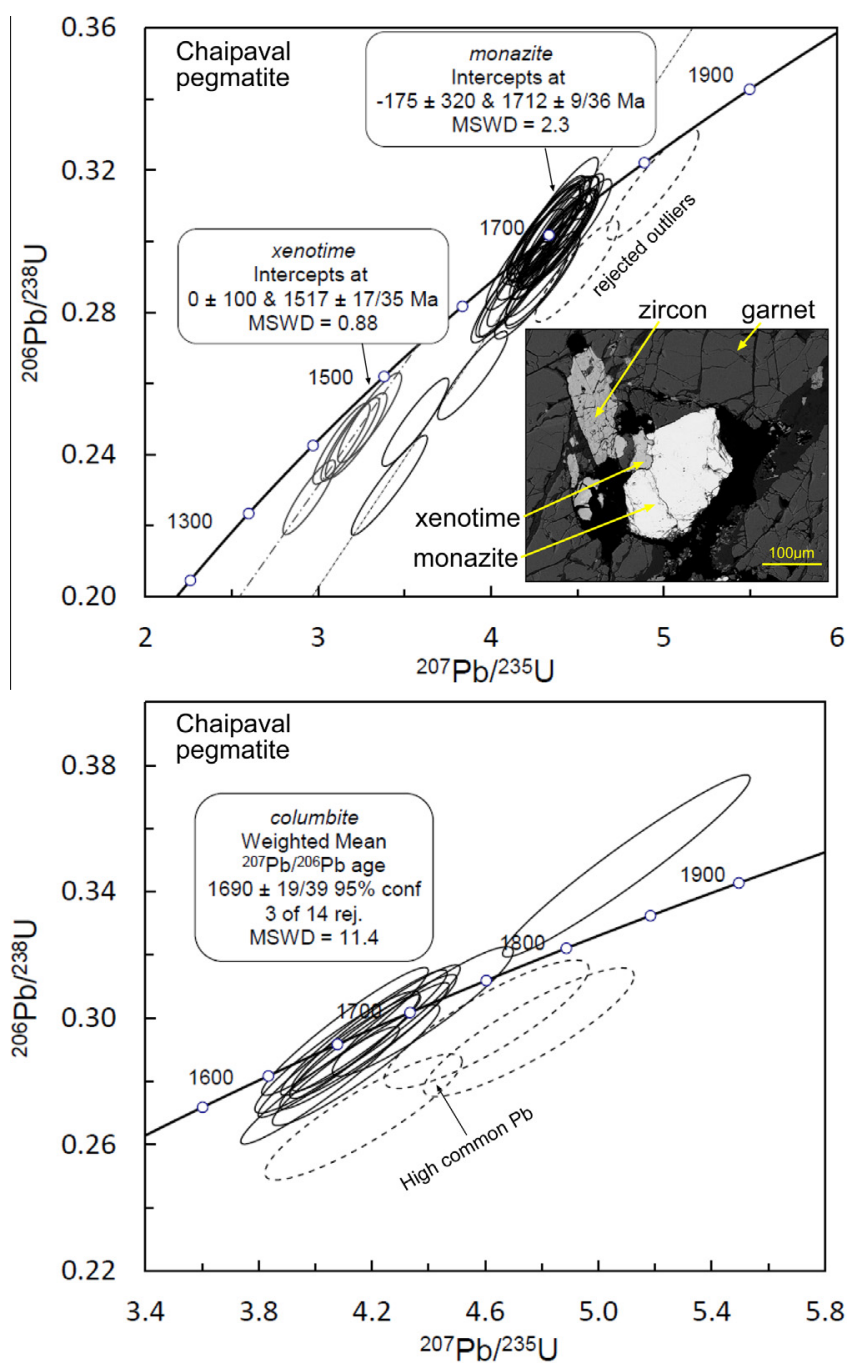

Fig. 13. Concordia plots for monazite and xenotime in sample HPR-020 with inset SEM-BSE image of monazite and xenotime from the Chaipaval pegmatite, and columbite in sample HPR-020 from the Chaipaval pegmatite. Analyses in black (monazite, columbite) or grey (xenotime) are those used for age calculation; those with dashed lines were rejected due to discordance or mixed age.

systems appear intact suggesting that the core of the monazite was shielded from fluid interaction. No other mineral reactions or replacement can be seen in this sample that may potentially be linked to a younger c. 1520 Ma event, thus it is interpreted that this younger fluid event did not affect the rare-metal mineral assemblage of interest. Interestingly, some previously published studies for pegmatites within the region ( $\mathrm{Rb}-\mathrm{Sr}, \mathrm{K}-\mathrm{Ar} \& \mathrm{U}-\mathrm{Pb}$ ) gave younger and imprecise ages that overlap the c. 1520 Ma age given here by xenotime (Table 1). Thus, a younger fluid infiltration event may also help to explain these anomalous ages.

Laxfordian granites and pegmatites occur throughout the Lewisian Gneiss Complex of NW Scotland, with those on the Outer Hebrides and in the southern mainland terranes spanning an age range of c.1700-1650 Ma. Thus the c. 1700 Ma age of the Chaivapal rare-metal pegmatite, falls within uncertainty of the main pegmatite emplacement event in these areas (Park et al., 2001; Mason et al., 2004a; Mason and Brewer, 2005; Kelly et al., 2008). Pegmatites in the Rhiconich and Assynt terranes are older (1790$1770 \mathrm{Ma}$ ), suggesting there have been at least two separate crustal melting episodes (Park et al., 2001; Mason et al., 2004a; Kelly et al., 2008; Goodenough et al., 2013). The new dates indicate that the rare-metal pegmatites were not formed at a different time to the other pegmatites in the Lewisian Gneiss Complex; rather it seems that rare-metal pegmatites and standard biotite-magnetite pegmatites in the southern parts of the Lewisian Gneiss Complex formed at the same time. The origin of these pegmatites is typically attributed to decompression melting of the crust after a major crustal-thickening event that affected the Lewisian (Watkins et al., 2007; Wheeler et al., 2010; Goodenough et al., 2013). Since the rare-metal pegmatites do not appear to be attributable to a different event or formation process, it seems clear that they must have formed by melting of a different source to the standard' biotite-magnetite pegmatites.

\subsection{Petrogenesis of rare-metal pegmatites}

The presence of two distinct pegmatite types in the HGB, i.e. muscovite-garnet-bearing (rare-metal) pegmatites and biotite-m agnetite-bearing (barren) pegmatites, which largely follow two distinct geochemical trends, has to be explained, as does the presence of pegmatites intermediate between these end-members. The apparent contemporaneity of the three types of pegmatite, within a relatively small area, means it is mot necessary to invoke differing processes to explain their genesis. The majority of Laxfordian pegmatites are considered to represent melting of local TTG crust in the presence of a K-rich fluid (Fettes et al., 1992; Castro, 2004; Watkins et al., 2007). Field relationships for pegmatites within the TTG gneiss terranes typically suggest a derivation by localised melting rather than fractionation of a parental granite at depth (Myers, 1971; Fettes et al., 1992; Goodenough et al., 2013). In contrast, field relationships in the HGB suggest that the pegmatite source magmas were not formed by melting of country rock at the current erosion level, but have instead risen from depth. In this area there has thus been potential for mixing of melts derived by partial melting of different sources. The HGB comprises very complex geology, including the metasedimentary and meta-igneous sources required to produce the observed spectrum of compositions.

\subsection{Muscovite-garnet (rare-metal) vs. biotite-magnetite (barren) pegmatites, and intermediate-types}

The majority of granitic pegmatites are intruded into TTG gneiss (most abundant in the Rhiconich, Tarbert, and southern mainland terranes), and these are typically biotite-magnetite (barren) pegmatites with a normal granitic mineralogy. The second pegmatite end-member is notably different, including a small number of muscovite-garnet-bearing (rare-metal) pegmatites that are almost all found intruded into the granulite facies, meta-igneous and metasedimentary island arc rocks (Baba, 1998) of the Harris Granulite Belt. The Chaipaval pegmatite is the main representative of this end-member type. The typical characteristics of these two end-members are summarised in Table 2. Pegmatites of the raremetal type are characterised by: (1) dominance of albitic plagioclase over microcline; (2) the presence of Mn-rich garnet and of muscovite as the dominant mica; and (3) the abundance of accessory minerals including $\mathrm{Nb}-\mathrm{Ta}$ minerals such as columbitetantalite. Pegmatites of both types occur in the Harris Granulite Belt, as first identified by von Knorring and Dearnley (1959), and in fact some pegmatites show intermediate characteristics. The Sletteval pegmatite, despite its large size and coarse grain-size, has the mineralogy of a typical biotite-magnetite pegmatite. In contrast, Chaipaval and the marginal zones of the Bhoiseabhal pegmatite are of the rare-metal pegmatite type. The only other pegmatite of this type sampled in this study is from Badcall Bay in the Assynt terrane. The intermediate pegmatites (e.g. Kyles House, Beinn Tharsuinn, the Bhoiseabhal summit pegmatite and the central parts of the Bhoiseabhal main pegmatite) typically contain gar- 
net, but little or no muscovite. Some of these pegmatites (Kyles House) do contain Y-Nb oxides.

It is particularly instructive to examine the pegmatites on a Shand index diagram where two distinct trends emerge that distinguish pegmatites of the muscovite-garnet (rare-metal) type (Fig. 6). The rare-metal pegmatites plot along a highly peraluminous trend, which is distinct from the trend followed by the more common biotite-magnetite (barren) pegmatites. Published data for rare-metal pegmatites (e.g. Tanco in Canada, Wodgina, Greenbushes, and Mount Cassiterite in north-western Australia and Seinäjoki in Finland (Partington et al., 1995; Mäkitie et al., 2001; Sweetapple and Collins, 2002; Stilling et al., 2006), also lie along this peraluminous, muscovite-garnet trend. The distinct trends observed on this diagram are likely to reflect compositional differences associated with the parental magmas, which have controlled the crystallisation of muscovite or biotite, rather than a gradual process such as fractionation of phases during pegmatite crystallisation. Muscovite-type micas, particularly those that have incorporated $\mathrm{Li}$, generally crystallise in environments depleted in $\mathrm{Fe}, \mathrm{Mg}$ and Ti (Monier and Robert, 1986). Conversely increasing concentrations of these elements would initiate the crystallisation of biotite (Scaillet et al., 1995). Therefore it seems reasonable to suggest that the more barren pegmatites crystallised from more mafic (and less peraluminous) magmas. The two trends overlap in the area of the diagram that is occupied by pegmatites composed largely of quartz and feldspar. However, this simple separation is made more complex by the Bhoiseabhal pegmatite, which has a biotite-magnetite core and margins that contain zones rich in muscovite and garnet. Furthermore, the intermediate pegmatites (e.g. Kyles House) contain small amounts of garnet, rare muscovite, and Y$\mathrm{Nb}$ oxides, but sit on the same trend as pegmatites that are clearly barren (e.g. Sletteval) on the Shand index plot. It is clear that magmas of varying peraluminosity were available within the HGB to form the pegmatites, and this suggests the likelihood of mixing of different sources.

Pegmatites of the biotite-magnetite type are characterised by typical granitic compositions, with high bulk-rock K/Rb ratios (K/ $\mathrm{Rb}>100$ ), and enrichment in $\mathrm{Sr}$ (up to $2717 \mathrm{ppm}$ ) and $\mathrm{Ba}$ (up to $8179 \mathrm{ppm}$ ) relative to $\mathrm{Rb}$ (up to $500 \mathrm{ppm}$ ). They also typically have relatively low contents of $\mathrm{Li}, \mathrm{Be}$ and $\mathrm{Cs}$ and have strong negative $\mathrm{Nb}-\mathrm{Ta}$ anomalies. As would be expected for pegmatites formed by melting of a plagioclase-rich, TTG source the pegmatites are relatively LREE-enriched and have flat or positive Eu anomalies (Rollinson, 2012). It is notable that intermediate-type pegmatites do have elevated concentrations of $\mathrm{Li}$, Be and $\mathrm{Cs}$, but not to the same extent as the muscovite-garnet type pegmatites. This can be explained in terms of the abundance of muscovite, which is an important carrier of these elements in pegmatites. The presence of $\mathrm{Nb}-\mathrm{Y}$ oxides, rather than columbite-tantalite minerals, in these pegmatites also explains the observed lower $\mathrm{Nb}-\mathrm{Ta}$ concentrations.

Although the rare-metal pegmatites represent only a small percentage of the Laxfordian pegmatites, an understanding of their origin has wider implications, especially for mineral exploration. Pegmatites of the rare-metal type are distinguished by their higher $\mathrm{A} / \mathrm{CNK}$ whole-rock values, lying along the highly peraluminous trend on the A/CNK diagram. They are also characterised by lower $\mathrm{K} / \mathrm{Rb}$ bulk-rock ratios, and enrichments in bulk-rock $\mathrm{Rb}, \mathrm{Li}, \mathrm{Nb}, \mathrm{Cs}$, $\mathrm{Be}$ and $\mathrm{Ta}$, and depletion in $\mathrm{Sr}$ and $\mathrm{Ba}$ relative to the biotite-magnetite pegmatite type. Notably, REE patterns for rare-metal pegmatites exhibit strong negative Eu anomalies and enrichment in the MREE and HREE compared to the LREE. Such strong negative Eu anomalies might indicate fractionation of plagioclase, melting of a plagioclase-depleted source material, or melting of a plagioclase-rich material, in which the plagioclase did not melt.

\subsection{Sources of pegmatites}

Based on their chemistry and mineralogy, muscovite-garnet (rare-metal) pegmatites in the HGB are most akin to LCT-type pegmatites, and thus likely to have an ultimate source in sedimentary rocks. According to Chappell and White (2001) S-type granites form by melting of sedimentary and/or metamorphosed sedimentary or supracrustal rocks, such as metapelites. Hence, the composition of pegmatites associated with S-type granites also mirrors that of the source material (e.g. LCT-type pegmatites are derived from fertile S-type granites) (Černý, 1991; Martin and De Vito, 2005; London, 2008; Černý et al., 2012a). The composition of a pegmatite should equally also mirror its source in situations where melting has occurred on a much more localised scale, without extensive fractionation. On this basis, it is reasonable to assume that the variations observed in $\mathrm{A} / \mathrm{CNK}$ values, trace element patterns and mineralogy between muscovite-garnet (rare-metal) pegmatites and biotite-magnetite (barren) pegmatites reflects the source, that different source materials were available for melting. We have found no evidence to suggest that the HGB pegmatites were formed by differing amounts of fractionation from a single parental granite.

Work by Rollinson (2012) has shown that partial melting of TTG gneiss would produce a melt depleted in Nb, Ta and the HREE. Johnson et al. (2012) has also shown that melting of Lewisian metagabbroic rocks produces REE patterns that are very similar to those observed in many Lewisian pegmatites (i.e. enrichment in the LREE; a positive Eu anomaly and depletion in the MREE

Table 2

Summary of the typical characteristics of biotite-magnetite pegmatites and rare-metal pegmatites in the Lewisian Gneiss Complex.

\begin{tabular}{|c|c|c|}
\hline & Biotite-magnetite pegmatite & Rare-metal pegmatite \\
\hline Age & c. $1675 \mathrm{Ma}^{*}$ & c. $1700 \mathrm{Ma}$ \\
\hline Host rock (protolith) & TTG-gneiss (igneous) & Garnet-kyanite-gneiss (sedimentary) \\
\hline Peak metamorphic grade & Amphibolite & Granulite \\
\hline Dominant feldspar & K-feldspar & Albite \\
\hline Dominant mica & Biotite & Muscovite \\
\hline Garnet composition & Garnet largely absent & Almandine-spessartine \\
\hline $\begin{array}{l}\text { Accessory mineral } \\
\text { assemblage }\end{array}$ & $\begin{array}{l}\text { Zircon; titanite; allanite; monazite; xenotime; } \\
\text { apatite }\end{array}$ & $\begin{array}{l}\text { Tourmaline; zircon; beryl; apatite; monazite; xenotime; ferrocolumbite; titanite; } \\
\text { gahnite }\end{array}$ \\
\hline Eu anomaly & Flat - strongly positive & Strongly negative \\
\hline $\mathrm{K} / \mathrm{Rb}$ & High - very high & Low \\
\hline $\mathrm{A} / \mathrm{CNK}$ & Moderate - high & Moderate - very high \\
\hline $\begin{array}{l}\text { Relative element } \\
\text { enrichment }\end{array}$ & $\mathrm{Ba}, \mathrm{Sr}, \mathrm{LREE}$ & Rb, Cs, Li, Ta, Nb, Be, Ga, HREE \\
\hline
\end{tabular}

"Friend and Kinny (2001). 
and HREE). The shape of REE patterns for the biotite-magnetite pegmatites within the TTG gneiss terranes (Fig. 8) shows distinct similarities to the modelled patterns derived from experimental work by Rollinson (2012) and Johnson et al. (2012). This supports field evidence indicating that these pegmatites probably formed by melting of TTG material. It has previously been suggested that the typical Laxfordian pegmatites could have been produced by melting of TTG gneisses with the addition of a K-rich hydrous fluid (Castro, 2004; Watkins et al., 2007), and it is generally agreed that pegmatite emplacement into the Lewisian gneisses occurred at the end of a period of continental collision and crustal thickening (Park, 2005; Goodenough et al., 2013; Mason, 2015). Overall there is little doubt that the majority of Laxfordian biotite-magnetite pegmatites in the Lewisian Gneiss Complex formed by melting of the TTG country rock, probably with addition of K-rich fluids during orogenesis.

The rare-metal pegmatites appear to be spatially associated with the Harris Granulite Belt, although bulk-rock and mineral chemistry clearly show that both muscovite-garnet (rare-metal) and barren, biotite-magnetite type pegmatites occur within the HGB. It is thus evident that more than one type of source was available in and around the HGB at the time of pegmatite formation. Rare-metal pegmatites are uncommon outside the HGB, although one example occurs in the Badcall Bay area of the Assynt terrane. Pegmatites are scarce in the Assynt terrane, which is interpreted as being due to the infertile nature of the TTG gneisses (Goodenough et al., 2013), and thus it seems likely that a volumetrically restricted source was available for the formation of the Badcall Bay pegmatite.

It is notable that the Badcall Bay pegmatite in Assynt is similar to rare-metal pegmatites in the HGB, in that it has similar enrichments in $\mathrm{Be}, \mathrm{Nb}, \mathrm{Cs}$ and $\mathrm{Ta}$, and also has similar REE-patterns (i.e. negative Eu anomaly and MREE enrichment). Notably, small amounts of garnet-bearing pelitic rocks are also a feature of this part of the Assynt terrane (the Eanruig supracrustals (Kinny and Friend, 2005; Zirkler et al., 2012). Although no such supracrustals have been described at outcrop in the immediate vicinity of Badcall Bay, they typically form lenses and pods up to c. $100 \mathrm{~m}$ long contained within the TTG gneisses, and such pods at depth represent a potential source for the Badcall pegmatite.

One possible explanation for the occurrence of rare-metal pegmatites could be the presence of a fertile parental granite at depth beneath the granulite belt, and that the rare-metal pegmatites simply represent highly evolved products derived by fractional crystallisation of that granitic magma. There is no evidence for such a major granitic body, but there is clear evidence for extensive crustal melting and formation of pegmatites throughout much of the Lewisian Gneiss Complex at the time of pegmatite formation (Myers, 1971; Cliff et al., 1998; Goodenough et al., 2013). A second possibility is that the rare-metal pegmatites simply represent the most fractionated products of localised granitic bodies formed by melting of the local TTG crust. However, the 'barren' trend on the $\mathrm{A} / \mathrm{CNK}$ diagram is considered to represent increasing fractionation of the biotite-magnetite pegmatite compositions. The divergent, rare-metal trend on the $\mathrm{A} / \mathrm{CNK}$ diagram contains compositions that are too peraluminous to have been formed by melting of TTG, indicating a different and more peraluminous source. Furthermore the second model does not explain the concentration of rare-metal pegmatites in the HGB. The third possible explanation, and the one that best fits the data, is that pegmatite composition is controlled by variations in the local crustal sources. The HGB represents one of the few areas within the Lewisian Gneiss Complex where reasonably large volumes of peraluminous metasedimentary rocks are potentially available as sources for melting. Smaller amounts of metasedimentary rocks are also present in the Assynt terrane (Kinny and Friend, 2005), although not always well mapped; such metasedimentary rocks may have provided a volumetrically limited source close to Badcall. It is notable that metasedimentary rocks in both these areas had been metamorphosed to granulite facies, and subsequently retrogressed, prior to pegmatite formation (Hollis et al., 2006; Baba et al., 2012; Zirkler et al., 2012). Regionally, metasedimentary rocks are also found in the Loch Maree Group, although these have not been metamorphosed to granulite facies (Park et al., 2001).

Metapelitic rocks provide a source of appropriate composition for the rare-metal pegmatite end-members, particularly Chaipaval. Many experimental studies have shown that peraluminous granites are typically formed by melting of biotite + muscovitebearing metapelites (Harris and Massey, 1994; Gardien et al., 1995; Patiño Douce and Harris, 1998). Biotite in the metapelites represents a host for elements such as $\mathrm{Li}, \mathrm{Rb}, \mathrm{Cs}, \mathrm{Nb}$ and Ta (Bea et al., 1994; Stepanov et al., 2014). They are also a potentially important source of $\mathrm{H}_{2} \mathrm{O}, \mathrm{F}$ and $\mathrm{Cl}$. Another important repository, in granulite facies rocks, for $\mathrm{Nb}$ and $\mathrm{Ta}$ is ilmenite (Nehring et al., 2010). In metapelite melting, these characteristic elements of rare-metal granites will typically partition into the melt (Icenhower and London, 1995). In contrast, the biotite-magnetite pegmatites formed from more mafic magmas; a possible source for these lies in the meta-igneous rocks of the HGB. These sources are interleaved, suggesting that any partial melts are likely to have mixed to varying degrees.

The distribution of the MREE and HREE is likely to be controlled by the presence of garnet, titanite, zircon, apatite, monazite and hornblende in the source material, particularly in granulite facies rocks (Bea and Montero, 1999). In the HGB, garnet-bearing pelitic rocks are found in the Leverburgh Belt; they contain biotite, muscovite, garnet, and accessory titanite, zircon, apatite, monazite, and secondary (retrograde) hornblende (Baba, 1998; Baba, 2003; Hollis et al., 2006). The retrogression of granulite-facies metasedimentary rocks in the Leverburgh Belt to amphibolite-facies prior to emplacement of the pegmatites was potentially an important precursor to their formation. The process of retrogression introduced fluids (this is reflected in the hydrous mineralogy of the retrogressed rocks) (Baba, 1998) and led to the breakdown of phases such as garnet, with formation of coronas (Hollis et al., 2006). The REE may have been unstable in these coronas, such that subsequent partial melting produced a partial melt enriched in the MREE and HREE. In summary, the mineral assemblage of metapelites in the Leverburgh Belt makes them an attractive potential source material for the production of rare-metal pegmatites in the HGB.

\subsection{Rare-metal pegmatite formation}

The Harris Granulite Belt underwent high-temperature granulite-facies metamorphism shortly after its formation around $1890 \mathrm{Ma}$ (Cliff et al., 1983; Baba, 1998, 1999; Hollis et al. 2006; Baba et al., 2012). Subsequent retrogression and decompression appears to have been associated with some component of partial melting, and was complete by c. $1870 \mathrm{Ma}$ (Baba et al. 2012). This was followed around $1740-1670$ Ma by late Laxfordian thrusting and crustal thickening with extensive amphibolite facies metamorphism and eventual development of extensional shear zones (Kinny and Friend, 2005; Park 2005; Love et al., 2010; Mason 2012, 2015; Goodenough et al.2013). Decompression melting of the crust towards the end of this event led to the formation of Laxfordian granites and pegmatites. This late Laxfordian event appears to have been diachronous in nature, with the granites in the northern terranes of the mainland being older than those elsewhere in the Lewisian (Goodenough et al. 2013) although more extensive geochronological datasets would be needed to confirm this.

In the Harris Granulite Belt, we propose that the c. 1870 Ma retrogression of high-grade metasedimentary rocks in the Leverburgh 
Belt to amphibolite facies, with accompanying rehydration and growth of biotite and muscovite (Baba, 1998), potentially played a vital role in re-fertilising the rocks of the HGB and allowing subsequent melting. This retrogression also led to the breakdown of minerals acting as repositories for important elements, such as garnet and monazite that might host the HFSE and REE (Baba, 2003; Hollis et al., 2006; Baba et al., 2012), thus potentially making these elements available during subsequent melting (Špaček et al., 2013). Garnet, rutile, zircon, apatite, monazite and hornblende are all known to be important hosts for the MREE and HREE and $\mathrm{Y}$ in magmatic and metamorphic systems (Bea, 1996). Partial melting of metasedimentary rocks that contain these phases might explain the HREE-enriched patterns observed in rare-metal pegmatites in the HGB.

Although in many areas the Laxfordian pegmatites of the Lewisian Gneiss Complex have been described as migmatites (e.g. Myers, 1971), the pegmatites within the HGB and at Badcall Bay do not show the same kind of link to their host rocks. Indeed, the pegmatites are cross-cutting, and there is limited evidence of host-rock melting. It therefore appears more likely that host-rock melting took place at depth within the HGB, and the magmas coalesced into small-scale magma lenses, which may have then undergone further fractionation. The more fractionated and fluid-rich of these magmas rose upwards to be emplaced as pegmatites at the current erosion level. A similar general model was proposed by Harris et al. (1986) who suggested that syn-collisional muscovite-bearing granites form during periods of crustal thickening. They propose that volatile-rich fluids moving upwards through the crustal pile during over-thrusting may interact with the overriding sheet to initiate partial melting. The resulting melts are likely to be enriched in $\mathrm{Rb}, \mathrm{B}, \mathrm{F}$ and Ta. A similar model has been described by Goodenough et al. (2013) for the formation of 'standard' biotite-magnetite-type pegmatites in the Rhiconich terrane. The wide range of potential source materials within the HGB explains the variability seen within the pegmatites over a relatively small area.

This work suggests that, in a province where anatectic granites and pegmatites are formed within a wide zone of compression and crustal thickening, the composition of those pegmatites may be more strongly controlled by the source materials that are available to melt, rather than by magmatic processes such as fractional crystallisation. This is the case even where relatively small amounts of metasedimentary rocks are present within a wider area of metaigneous crustal protoliths. Exploration targeting for rare-metal pegmatites may be better focused, not just on areas with large volumes of potential parent granites, but also in areas where appropriate sources are available.

There are numerous examples (i.e. New Mexico, Australia, Canada, China and the Czech Republic) of economic rare-metal pegmatites that are found in high-grade metamorphic terranes comprising amphibolite to granulite facies metasedimentary rocks and migmatites (Jahns and Ewing, 1976; Marignac and Cuney, 1999; Sweetapple and Collins, 2002; Stilling et al., 2006; Wang et al., 2007; Küster et al., 2009; McKechnie et al., 2012; Melleton et al., 2012; Martins et al., 2013). It is possible that the composition of available protoliths for melting is more important for rare-metal pegmatites than large-volume melting and formation of a fertile parent granite that undergoes lengthy fractionation.

\section{Conclusions}

This work shows that, whilst the majority of Laxfordian pegmatites in the Lewisian Gneiss Complex are 'typical' biotite-magnetite granitic pegmatites, a small suite of rare-metal pegmatites is also found.
Muscovite-garnet-bearing rare-metal pegmatites in the Lewisian are largely found in the metasedimentary rocks of the Harris Granulite Belt, although one pegmatite of similar composition occurs at Badcall Bay in the Assynt Terrane. These pegmatites are highly peraluminous, have low bulk-rock $\mathrm{K} / \mathrm{Rb}$ ratios, and are notably enriched in $\mathrm{Rb}, \mathrm{Li}, \mathrm{Cs}, \mathrm{Be}, \mathrm{Nb}$ and Ta compared to the biotitemagnetite-type pegmatites. The mineralogy of the rare-metal pegmatites is dominated by albitic feldspar, muscovite mica and Mnrich spessartine garnet. They also contain an exotic suite of accessory minerals that include ferrocolumbite, beryl, gahnite and aeschynite-(Y). The mineralogy and chemistry of the rare-metal pegmatites suggests that they formed by melting of a peraluminous source enriched in a range of LILE and HFSE elements.

New dating places formation of the rare-metal pegmatites at about $1700 \mathrm{Ma}$; this indicates that rare-metal pegmatites formed contemporaneously with biotite-magnetite pegmatites in adjacent terranes, supporting the idea that the main control on compositional variation is the magmatic source, rather than the genetic processes. This suggests that regardless of the melting mechanism source lithology plays a very important role in the formation of rare-metal pegmatites. As such, exploration for rare-metal pegmatites should focus on high-grade metamorphic terranes dominated by amphibolite to granulite facies metasedimentary lithologies.

\section{Acknowledgments}

This paper is published with the permission of the Executive Director of the British Geological Survey. Constructive reviews by Hugh Rollinson and an anonymous reviewer, and editorial advice from Randy Parrish, were much appreciated and greatly improved the paper. The Inorganic Geochemistry Laboratories at the BGS are thanked for their analytical support. Mick Strutt is also thanked for his assistance in the field.

\section{Appendix A. Supplementary data}

Supplementary data associated with this article can be found, in the online version, at http://dx.doi.org/10.1016/j.precamres.2016. 06.008.

\section{References}

Baadsgaard, H., Černý, P., 1993. Geochronological studies in the Winnipeg River pegmatite populations, southeastern Manitoba. Geological Association of Canada-Mineralogical Association of Canada Joint Annual Meeting, A5.

Baba, S., 1998. Geology and geochemical characteristics of the leverburgh belt in South Harris, outer Hebrides, Northwest Scotland. J. Geosci. Osaka City Univ. 40, $119-143$.

Baba, S., 1999. Sapphirine-bearing orthopyroxene-kyanite/sillimanite granulites from South Harris, NW Scotland: evidence for Proterozoic UHT metamorphism in the Lewisian. Contrib. Miner. Petrol. 136, 33-47.

Baba, S., 2003. Two stages of sapphirine formation during prograde and retrograde metamorphism in the Palaeoproterozoic Lewisian complex in South Harris, NW Scotland. J. Petrol. 44, 329-354.

Baba, S, Dunkley, D.J. Hokada, T, Horie, K. Suzuki, K. Shiraishi, K, 2012. New SHRIMP U-Pb zircon ages and CHIME monazite ages from South Harris granulites, Lewisian Complex, NW Scotland: implications for two stages of zircon formation during Palaeoproterozoic UHT metamorphism. Precambr. Res. 200-203, 104-128.

Bea, F., Pereira, M.D., Stroh, A., 1994. Mineral/leucosome trace-element partitioning in a peraluminous migmatite (a laser ablation-ICP-MS study). Chem. Geol. 117, $291-312$.

Bea, F., 1996. Residence of REE, Y, Th and U in granites and crustal protoliths; implications for the chemistry of crustal melts. J. Petrol. 37, 521-552.

Bea, F., Montero, P., 1999. Behavior of accessory phases and redistribution of Zr, REE $\mathrm{Y}$, Th, and U during metamorphism and partial melting of metapelites in the lower crust: an example from the Kinzigite Formation of Ivrea-Verbano, NW Italy. Geochim. Cosmochim. Acta 63, 1133-1153. 
Beach, A., Coward, M.P., Graham, R.H., 1974. An interpretation of the structural evolution of the Laxford front. Scott. J. Geol. 9, 297-308.

Beacom, L.E., Holdsworth, R.E., McCaffrey, K.J.W., Anderson, T.B., 2001. A quantitative study of the influence of pre-existing compositional and fabric heterogeneities upon fracture-zone development during basement reactivation, 186. Geological Society, London, Special Publications, 195-211.

Belkasmi, M., Cuney, M., Pollard, P.J., Bastoul, A., 2000. Chemistry of the Ta-Nb-SnW oxide minerals from the Yichun rare metal granite (SE China): genetic implications and comparison with Moroccan and French Hercynian examples. Mineral. Mag. 64, 507-523.

Bowie, S.H.U., 1964. Annual Report of the Atomic Energy Division: Summary of Progress of the Geological Survey of GB \& Museum of Practical Geology. Geological Survey of Great Britain, 75-76.

Brögger, W.C., 1890. Die Mineralien der Syenitpegmatitgänge der Südnorwegischen Augit und Nephelinsyenite. Z. Kristallograph. Mineral. 16, 1-63.

Carson, C.J., Powell, R., Wilson, C.J.L., Dirks, P.H.G.M., 1997. Partial melting during tectonic exhumation of a granulite terrane: an example from the Larsemann Hills, East Antarctica. J. Metamorph. Geol. 15, 105-126.

Cartwright, I., Fitches, W.R., O'Hara, M.J., Barnicoat, A.C., O'Hara, S., 1985. Archaean supracrustal rocks from the Lewisian near Stoer, Sutherland. Scott. J. Geol. 21, 187-196.

Castro, A., 2004. The source of granites: inferences from the Lewisian complex. Scott. J. Geol. 40, 49-65.

Černý, P., Macek, J., 1972. The Tanco pegmatite at Bernic Lake, Manitoba; V, Coloured potassium feldspars. Can. Mineral. 11, 679-689.

Černý, P., Trueman, D.L., Ziehlke, D.V., Goad, B.E., Paul, B.J., 1981. The Cat Lake Winnipeg River and the Wekusko Lake pegmaite fields, Manitoba.

Černý, P., Meintzer, R.E., Anderson, A.J., 1985. Extreme fractionation in rare-element granitic pegmatites; selected examples of data and mechanisms. Can. Mineral. 23, 381-421.

Černý, P., 1989. Contrasting geochemistry of two pegmatite fields in Manitoba: products of juvenile Aphebian crust and polycyclic Archean evolution. Precambr. Res. 45, 215-234.

Černý, P., 1991. Fertile granites of Precambrian rare-element pegmatite fields: is geochemistry controlled by tectonic setting or source lithologies? Precambr. Res. 51, 429-468.

Černý, P., 1992. Geochemical and petrogenetic features of mineralization in rareelement granitic pegmatites in the light of current research. Appl. Geochem. 7, 393-416.

Černý, P., Ercit, T.S., 2005. The Classification of granitic pegmatites revisited. Can. Mineral. 43, 2005-2026.

Černý, P., London, D., Novák, M., 2012a. Granitic pegmatites as reflections of their sources. Elements 8, 289-294.

Černý, P., Teertstra, D.K., Chapman, R., Selway, J.B., Hawthorne, F.C., Ferreira, K., Chackowsky, L.E., Wang, X.-J., Meintzer, R.E., 2012b. Extreme fractionation and deformation of the leucogranite-pegmatite suite at Red Cross Lake, Manitoba, Canada (IV. Mineralogy). Can. Mineral. 50, 1839-1875.

Chakoumakos, B.C., Lumpkin, G.R., 1990. Pressure-temperature constraints on the crystallization of the Harding Pegmatite, Taos County, New Mexico. Can. Mineral. 28, 287-298.

Chappell, B.W., White, A.J.R., 2001. Two contrasting granite types: 25 years later. Aust. J. Earth Sci. 48, 489-499.

Chew, D.M., Sylvester, P.J., Tubrett, M.N., 2011. U-Pb and Th-Pb dating of apatite by LA-ICPMS. Chem. Geol. 280, 200-216.

Cliff, R.A., Gray, C.M., Huhma, H., 1983. A Sm-Nd isotopic study of the South Harris Igneous complex, the Outer Hebrides. Contrib. Miner. Petrol. 82, 91-98.

Cliff, R.A., Rex, D.C., Guise, P.G., 1998. Geochronological studies of Proterozoic crustal evolution in the northern Outer Hebrides. Precambr. Res. 91, 401-418.

Coward, M.P., 1990. Shear zones at the Laxford front, NW Scotland and their significance in the interpretation of lower crustal structure. J. Geol. Soc. London 147, 279-286.

Crouse, R.A., Černý, P., 1972. The Tanco pegmatite at Bernic Lake, Manitoba; I, Geology and paragenesis. Can. Mineral. 11, 591-608.

Dahlquist, J.A., Galindo, C., Pankhurst, R.J., Rapela, C.W., Alasino, P.H., Saavedra, J. Fanning, C.M., 2007. Magmatic evolution of the Peñón Rosado granite: petrogenesis of garnet-bearing granitoids. Lithos 95, 177-207.

Davies, F.B., 1974. A layered basic complex in the Lewisian, south of Loch Laxford, Sutherland. J. Geol. Soc. London 130, 279-284.

De Beaumont, E., 1847. Note sur les émanations volcaniques et métallifères. Société Géologique de France 12, 1249.

Dearnley, R., 1963. The Lewisian complex of South Harris With some observations on the metamorphosed basic intrusions of the Outer Hebrides, Scotland. Quart. J. Geol. Soc. 119, 243-307.

Dickinson, B.B., 1974. Metamorphic evolution of the Leverbugh supracrustal belt, South Harris, with special reference to textural variations Unpublished PhD thesis. University of London.

du Bray, E.A., 1988. Garnet compositions and their use as indicators of peraluminous granitoid petrogenesis - southeastern Arabian Shield. Contrib. Miner. Petrol. 100, 205-212.

Fettes, D.J., Mendum, J.R., Smith, D.I., Watson, J.V., 1992. Geology of the Outer Hebrides. British Geological Survey Memoir.

Fitzsimons, I.C.W., 1996. Metapelitic Migmatites from Brattstrand Bluffs, East Antarctica-Metamorphism, Melting and Exhumation of the Mid Crust. J. Petrol, 37, 395-414.
Franz, G., Smelik, E.A., 1995. Zoisite-clinozoisite bearing pegmatites and their importance for decompressional melting in eclogites. Eur. J. Mineral. 7, 14211436.

Friend, C.R.L., Kinny, P.D., 2001. A reappraisal of the Lewisian Gneiss Complex: geochronological evidence for its tectonic assembly from disparate terranes in the Proterozoic. Contrib. Miner. Petrol. 142, 198-218.

Gardien, V., Thompson, A.B., Grujic, D., Ulmer, P., 1995. Experimental melting of biotite + plagioclase + quartz \pm muscovite assemblages and implications for crustal melting. J. Geophys. Res.: Solid Earth 100, 15581-15591.

Gilbert, H.P., 2007. Stratigraphic investigations in the Bird River greenstone belt, Manitoba. Manitoba Geol. Survey, 129-143.

Gilbert, H.P., 2008. Stratigraphic investigations in the Bird River greenstone belt, Manitoba. Manitoba Geol. Survey, 121-138.

Giletti, B.J., Moorbath, S., Lambert, R.S.J., 1961. A geochronological study of the metamorphic complexes of the Scottish Highlands. Quart. J. Geol. Soc. London $117,233-264$.

Gillespie, M., Styles, M., 1999. BGS rock classification scheme. Classification of igneous rocks 1.

Goodenough, K.M., Park, R.G., Krabbendam, M., Myers, J.S., Wheeler, J., Loughlin, S., Crowley, Q.L.F.C.R., Beach, A., Kinny, P.D., Graham, R., 2010. The Laxford Shear Zone: an end-Archaean terrane boundary? In: Law, R., Butler, R.W.H. Holdsworth, R.E., Krabbendam, M., Strachan, R. (Eds.), Continental Tectonics and Mountain Building. The Geological Society, London, pp. 101-118.

Goodenough, K.M., Crowley, Q.G., Krabbendam, M., Parry, S.F., 2013. New U-Pb age constraints for the Laxford Shear Zone, NW Scotland: Evidence for tectonomagmatic processes associated with the formation of a Palaeoproterozoic supercontinent. Precambr. Res. 233, 1-19.

Goodenough, K.M., Lusty, P.A.J., Roberts, N.M.W., Key, R.M., Garba, A., 2014. Postcollisional Pan-African granitoids and rare metal pegmatites in western Nigeria: Age, petrogenesis, and the 'pegmatite conundrum'. Lithos 200-201, 22-34.

Harlov, D.E., Hetherington, C.J., 2010. Partial alteration of monazite and xenotime during mineral-fluid interaction: implications for geochronology. Am. Mineral 95, 1105-1108.

Harris, N., Massey, J., 1994. Decompression and anatexis of Himalayan metapelites. Tectonics 13, 1537-1546.

Harris, N.B.W., Pearce, J.A., Tindle, A.G., 1986. Geochemical characteristics of collision-zone magmatism. Geological Society, London, Special Publications 19, 67-81.

Hetherington, C.J., Harlov, D.E., 2008. Metasomatic thorite and uraninite inclusions in xenotime and monazite from granitic pegmatites, Hidra anorthosite massif, southwestern Norway: mechanics and fluid chemistry. Am. Mineral. 93, 806820 .

Hitchcock, E., 1883. Report on the geology, mineralogy, botany, and zoology of Massachusetts. Massachusetts Geological Survey Report.

Holland, J.G., Lambert, R.S., 1995. The geochemistry and geochronology of the gneisses and pegmatites of the Tollie antiform in the Lewisian complex of northwestern Scotland. Can. J. Earth Sci. 32, 496-507.

Hollis, J.A., Harley, S.L., White, R.W., Clarke, G.L., 2006. Preservation of evidence for prograde metamorphism in ultrahigh-temperature, high-pressure kyanite-bearing granulites, South Harris, Scotland. J. Metamorph. Geol. 24, 263-279.

Horsley, R.J., 1978. Geochemistry of meta-igneous rocks from the South harris complex, Outer Hebrides Unpublished PhD thesis. University of London.

Horstwood, M.S.A., Košler, J., Gehrels, G., Jackson, S.E., McLean, N.M., Paton, C., Pearson, N.J., Sircombe, K., Sylvester, P., Vermeesch, P., Bowring, J.F., Condon, D. J., Schoene, B., 2016. Community-derived standards for LA-ICP-MS U-Th-Pb geochronology - uncertainty propagation, age interpretation and data reporting. Geostand. Geoanal. Res.

Hunt, T.S., 1871. Notes on granitic rocks. Am. J. Sci. 101 (82-89), 182-191.

Icenhower, J., London, D., 1995. An experimental study of element partitioning among biotite, muscovite, and coexisting peraluminous silicic melt at $200 \mathrm{MPa}$ $\left(\mathrm{H}_{2} \mathrm{O}\right)$. Am. Mineral. 80, 1229-1251.

Icenhower, J., London, D., 1996. Experimental partitioning of Rb, Cs, Sr, and Ba between alkali feldspar and peraluminous melt. Am. Mineral., p. 719.

Jahns, R.H., Ewing, R.C., 1976. The Harding mine, Taos County. New Mexico Geological Society, New Mexico.

Jehu, T.J., Craig, R.M., 1927. XX.-Geology of the Outer Hebrides. Part IV.-South Harris. Earth Environ. Sci. Trans. R. Soc. Edinb. 55, 457-488.

Johnson, T.E., Fischer, S., White, R.W., Brown, M., Rollinson, H.R., 2012. Archaean intracrustal differentiation from partial melting of metagabbro - Field and geochemical evidence from the central region of the Lewisian Complex, NW Scotland. J. Petrol. 53, 2115-2138.

Kelly, N.M., Hinton, R.W., Harley, S.L., Appleby, S.K., 2008. New SIMS U-Pb zircon ages from the Langavat Belt, South Harris, NW Scotland: implications for the Lewisian terrane model. J. Geol. Soc. London 165, 967-981.

Kinny, P.D., Friend, C.R.L.J.L.G., 2005. Proposal for a terrane-based nomenclature for the Lewisian Complex of NW Scotland. J. Geol. Soc. London 162, 175-186.

Küster, D., Romer, R., Tolessa, D., Zerihun, D., Bheemalingeswara, K., Melcher, F., Oberthür, T., 2009. The Kenticha rare-element pegmatite, Ethiopia: interna differentiation, U-Pb age and Ta mineralization. Miner. Deposita 44, 723-750.

Lappalainen, R., Neuvonen, K.J., 1968. Trace elements in some Finnish pegmatitic potassium fledspars. Bull. Geol. Soc. Finland 40, 59-64.

London, D., 2005. Granitic pegmatites: an assessment of current concepts and directions for the future. Lithos 80, 281-303.

London, D., 2008. Pegmatites. Can. Mineral., Special Publication 
London, D., 2014. A petrologic assessment of internal zonation in granitic pegmatites. Lithos 184-187, 74-104.

Love, G.J., Friend, C.R.L., Kinny, P.D., 2010. Palaeoproterozoic terrane assembly in the Lewisian Gneiss Complex on the Scottish mainland, south of Gruinard Bay: SHRIMP U-Pb zircon evidence. Precambr. Res. 183, 89-111.

MacDonald, J.M., Wheeler, J., Harley, S.L., Mariani, E., Goodenough, K.M., Crowley, Q., Tatham, D., 2013. Lattice distortion in a zircon population and its effects on trace element mobility and U-Th-Pb isotope systematics: examples from the Lewisian Gneiss Complex, northwest Scotland. Contrib. Miner. Petrol. 166, 21 41.

MacDonald, J.M., Goodenough, K.M., Wheeler, J., Crowley, Q., Harley, S.L., Mariani, E., Tatham, D., 2015. Temperature-time evolution of the Assynt Terrane of the Lewisian Gneiss Complex of Northwest Scotland from zircon U-Pb dating and $\mathrm{T}$ thermometry. Precambr. Res. 260, 55-75.

Mäkitie, H., Kärkkäinen, N., Lahti, S.I., Alviola, R., 2001. Compositional variation of granitic pegmatites in relation to regional metamorphism in the Seinäjoki region, western Finland. In: Mäkitie, H. (Ed.), Svecofennian granitic pegmatites $(1.86-1.79 \mathrm{Ga})$ and quartz monzonite $(1.87 \mathrm{Ga})$, and their metamorphic environment in the Seinäjoki region, western Finland. Geological Survey of Finland, Espoo, pp. 31-59.

Marignac, C., Cuney, M., 1999. Ore deposits of the French Massif Central: insight into the metallogenesis of the Variscan collision belt. Miner. Deposita 34, 472504.

Martin, R.F., De Vito, C., 2005. The patterns of enrichment in felsic pegmatites ultimately depend on tectonic setting. Can. Mineral. 43, 2027-2048.

Martins, T., Kremer, P., Vanstone, P., 2013. The Tanco mine: geological setting internal zonation and mineralogy of a world-class rare element pegmatite deposit, Geological Association of Canada-Mineralogical Association of Canada Joint Annual Meeting. Manitoba Geological Survey, Open File OF2013-8, p. 17.

Mason, A.J., Brewer, T.S., 2004. Mafic dyke remnants in the Lewisian complex of the Outer Hebrides, NW scotland: a geochemical record of continental break-up and re-assembly. Precambr. Res. 133, 121-141.

Mason, A.J., Parrish, R.R., Brewer, T.S., 2004a. U-Pb geochronology of Lewisian orthogneisses in the Outer Hebrides, Scotland: implications for the tectonic setting and correlation of the South Harris Complex. J. Geol. Soc. 161, 45-54.

Mason, A.J., Temperley, S., Parrish, R.R., 2004b. New light on the construction, evolution and correlation of the Langavat Belt (Lewisian Complex), Outer Hebrides, Scotland: field, petrographic and geochronological evidence for an early Proterozoic imbricate zone. J. Geol. Soc. London 161, 837-848.

Mason, A.J., Brewer, T.S., 2005. A re-evaluation of a Laxfordian terrane boundary in the Lewisian Complex of South Harris, NW Scotland. J. Geol. Soc. London 162, 401-408.

Mason, A.J., 2012. Major early thrusting as a control on the Palaeoproterozoic evolution of the Lewisian Complex: evidence from the Outer Hebrides, NW Scotland. J. Geol. Soc. London 169, 201-212.

Mason, A.J., 2015. The Palaeoproterozoic anatomy of the Lewisian Complex, NW Scotland: evidence for two 'Laxfordian' tectonothermal cycles. J. Geol. Soc

McDonough, W.F., Sun, S.S., 1995. The composition of the Earth. Chem. Geol. 120, 223-253.

McKechnie, C.L., Annesley, I.R., Ansdell, K.M., 2012. Medium- to low-pressure pelitic gneisses of Fraser Lakes Zone-B, Wollaston Domain, Northern Saskatchewan, Canada: mineral compositions, metamorphic p-t-t path, and implications for the genesis of radioactive abyssal granitic pegmatites. Can. Mineral. 50, 16691694.

Melleton, J., Gloaguen, E., Frei, D., Novák, M., Breiter, K., 2012. How are the emplacement of rare-element pegmatites, regional metamorphism and magmatism interrelated in the Moldanubian domain of the Variscan Bohemian Massif, Czech Republic? Can. Mineral. 50, 1751-1773.

Monier, G., Robert, J.-L., 1986. Evolution of the miscibility gap between muscovite and biotite solid solutions with increasing lithium content: an experimenta study in the system $\mathrm{K}_{2} \mathrm{O}-\mathrm{Li}_{2} \mathrm{O}-\mathrm{MgO}-\mathrm{FeO}-\mathrm{Al}_{2} \mathrm{O}_{3}-\mathrm{SiO}_{2}-\mathrm{H}_{2} \mathrm{O}-\mathrm{HF}$. Mineral. Mag. $50,641-651$

Moorbath, S., Park, R.G., 1972. The Lewisian chronology of the southern region of the Scottish mainland. Scott. J. Geol. 8, 51-74.

Mottram, C.M., Parrish, R.R., Regis, D., Warren, C.J., Argles, T.W., Harris, N.B.W. Roberts, N.M.W., 2015. Using U-Th-Pb petrochronology to determine rates of ductile thrusting: time windows into the Main Central Thrust, Sikkim Himalaya. Tectonics 34, 1355-1374.

Müller, A., Kearsley, A., Spratt, J., Seltmann, R., 2012. Petrogenetic implications of magmatic garnet in granitic pegmatites from Southern Norway. Can. Mineral. 50, 1095-1115.

Myers, J.S., 1971. The Late Laxfordian granite-migmatite complex of western Harris, Outer Hebrides. Scott. J. Geol. 7, 254-284.

Nehring, F., Foley, S., Hölttä, P., 2010. Trace element partitioning in the granulite facies. Contrib. Miner. Petrol. 159, 493-519.

Novák, M., Škoda, R., Gadas, P., Krmíček, L., Černý, P., 2012. Contrasting origins of the mixed (NYF + LCT) signature in granitic pegmatites, with examples from the moldanubian zone, Czech Republic. Can. Mineral. 50, 1077-1094.

Owen, L.J., 2013. An Investigation into the distribution of niobium, tantalum and rare earth elements in granitoid pegmatites, in the Gairloch Area, NW Scotland, Camborne School of Mines. Univeristy of Exeter.

Pan, Y., Breaks, F.W., 1997. Rare-earth elements in fluorapatite, separation Lake area, Ontario; evidence for S-type granite-rare-element pegmatite linkage. Can. Mineral. 35, 659-671.
Park, R.G., Tarney, J., Connelly, J.N., 2001. The Loch Maree Group: palaeoproterozoic subduction-accretion complex in the Lewisian of NW Scotland. Precambr. Res. $105,205-226$

Park, R.G., 2002. The Lewisian geology of Gairloch. Geological Society of London, London, NW Scotland, p. 80.

Park, R.G., 2005. The Lewisian terrane model: a review. Scott. J. Geol. 41, 105-118.

Partington, G.A., McNaughton, N.J., Williams, I.S., 1995. A review of the geology, mineralization, and geochronology of the Greenbushes Pegmatite, Western Australia. Econ. Geol. 90, 616-635.

Patiño Douce, A.E., Harris, N., 1998. Experimental constraints on Himalayan Anatexis. J. Petrol. 39, 689-710.

Peach, B.N., Horne, J., Gunn, W., Clough, C.T., Hinxman, L.W., Teall, J.J.H., 1907. The geological structure of the North-West Highlands of Scotland. Memoir of the Geological Survey of Great Britain 668, 652 plates.

Peach, B.N., 1913. The geology of the Fannich mountains and the country around Upper Loch Maree and Strath Broom: (explanation of sheet 92). H.M.S.O, Edinburgh.

Pin, C., Monchoux, P., Paquette, J.-L., Azambre, B., Wang, R.C., Martin, R.F., 2006. Igneous albitite dikes in orogenic lherzolites, western Pyrénées, France: a possible source for corundum and alkali feldspar xenocrysts in basaltic terranes. II. geochemical and petrogenetic considerations. Can. Mineral. 44, 843-856.

Rollinson, H., 2012. Geochemical constraints on the composition of Archaean lower continental crust: partial melting in the Lewisian granulites. Earth Planet. Sci. Lett. 351-352, 1-12.

Scaillet, B., Pichavant, M., Roux, J., 1995. Experimental crystallization of leucogranite magmas. J. Petrol. 36, 663-705.

Selway, J.B., Breaks, F.W., Tindle, A.G., 2005. A review of rare-element (Li-Cs-Ta) pegmatite exploration techniques for the Superior Province, Canada, and large worldwide tantalum deposits. Explor. Min. Geol. 14, 1-30.

Shand, S.J., 1943. Eruptive rocks: their genesis, composition, classification, and their relation to ore deposits with a chaper on meteorites.

Sherlock, S.C., Jones, K.A., Park, R.G., 2008. Grenville-age pseudotachylite in the Lewisian: laserprobe $40 \mathrm{Ar} / 39 \mathrm{Ar}$ ages from the Gairloch region of Scotland. J. Geol. Soc. London 165, 73-83.

Siivola, J., Schmid, R., 2007. List of mineral abbreviations. Cambridge University Press, New York, pp. 93-110.

Špaček, P., Ackerman, L., Habler, G., Abart, R., Ulrych, J., 2013. Garnet breakdown, symplectite formation and melting in basanite-hosted peridotite xenoliths from Zinst (Bavaria, Bohemian Massif). J. Petrol. 54, 1691-1723.

Stepanov, A.A., Mavrogenes, J., Meffre, S., Davidson, P., 2014. The key role of mica during igneous concentration of tantalum. Contrib. Miner. Petrol. 167, 1-8.

Stilling, A., Cerný, P., Vanstone, P.J., 2006. The Tanco Pegmatite at Bernic Lake, Manitoba. XVI. Zonal and bulk compositions and their petrogenetic significance. Can. Mineral. 44, 599-623.

Sutton, J., Watson, J.V., 1951. The pre-Torridonian metamorphic history of the Loch Torridon and Scourie areas in the northwest Highlands, and its bearing on the chronological classification of the Lewisian. Quart. J. Geol. Soc. London 106, 241-307.

Sweetapple, M.T., Collins, P.L.F., 2002. Genetic framework for the classification and Distribution of Archean rare metal pegmatites in the North Pilbara Craton, Western Australia. Econ. Geol. 97, 873-895.

Tarney, J., Weaver, B.L., 1987. Geochemistry of the Scourian complex: petrogenesis and tectonic models. In: Park, R.G., Tarney, J. (Eds.), Evolution of the Lewisian and Comparable Precambrian High Grade Terrains. Geological Society of London, London, pp. 45-56.

Taylor, P.N., Jones, N.W., Moorbath, S., 1984. Isotopic Assessment of Relative Contributions from Crust and Mantle Sources to the Magma Genesis of Precambrian Granitoid Rocks. Philos. Trans. R. Soc. 310, 605-625.

Tindle, A.G., Breaks, F.W., 1998. Oxide minerals of the separation rapids rare-element granitic pegmatite group, northwestern Ontario. Can. Mineral. 36, 609-635.

Tindle, A.G., Breaks, F.W., 2000. Columbite-tantalite mineral chemistry from rareelement granitic pegmatites: separation Lake area, N.W. Ontario, Canada. Mineral. Petrol. 70, 165-198.

Tischendorf, G., Förster, H.-J., Gottesmann, B., 2001. Minor- and trace-element composition of trioctahedral micas: a review. Mineral. Mag. 65, 249-276.

van Breemen, O., Aftalion, M., Pidgeon, R.T., 1971. The age of the granitic injection complex of Harris, Outer Hebrides. Scott. J. Geol. 7, 139-152.

von Knorring, O., Dearnley, R., 1959. The Lewisian pegmatites of South Harris, Outer Hebrides.

Walawender, M.J., 2003. Garnet-bearing granitoids and pegmatite dikes in the Indian Hill-Tule Mountain roof pendant: Implications for the origin of gembearing pegmatites in southern California. Geology of the Elsinore Fault Zone, San Diego region. Edited by ML Murbach and MW Hart. San Diego Association of Geologists and South Coast Geological Society Annual Field Guide, 27-38.

Wang, T., Tong, Y., Jahn, B.-M., Zou, T.-R., Wang, Y.-B., Hong, D.-W., Han, B.-F., 2007. SHRIMP U-Pb Zircon geochronology of the Altai No. 3 Pegmatite, NW China, and its implications for the origin and tectonic setting of the pegmatite. Ore Geol. Rev. 32, 325-336.

Wang, X., 1993. Uranium-lead zircon geochronology study of the Bird River greenstone belt, southeastern Manitoba. University of Windsor, Ontario, p. 96.

Watkins, J.M., Clemens, J.D., Treloar, P.J., 2007. Archean TTGs as sources of younger granitic magmas: melting of sodic metatonalites at 0.6-1.2 GPa. Contrib. Miner. Petrol. 154, 91-110.

Webber, K., Simmons, W.B., 2007. Crystallization dynamics. In: Martins, T., Vieira, R. (Eds.), Granitic Pegmatites. The State of the Art, Portugal, pp. 17-19. 
Westbrook, G.K., 1974. The South Harris magnetic anomaly. Proc. Geol. Assoc. 85, 1 -

Wheeler, J., Park, R.G., Rollinson, H.R., Beach, A., 2010. The Lewisian Complex: insights into deep crustal evolution. In: Law, R., Butler, R.W.H., Holdsworth, R.E., Krabbendam, M., Strachan, R. (Eds.), Continental Tectonics and Mountain Building: the Legacy of Peach and Horne. The Geological Society, London, pp. $51-79$.

Whitehouse, M.J., Bridgwater, D., 2001. Geochronological constraints on Paleoproterozoic crustal evolution and regional correlations of the northern Outer Hebridean Lewisian complex, Scotland. Precambr. Res. 105, 227-245.
Witty, G.J., 1975. The geochemistry of Roneval Anorthosite, South harris, Scotland. Unpublished PhD thesis. University of London.

Woodhead, J.D., Hergt, J.M., 2001. Strontium, neodymium and lead isotope analyses of NIST glass certified reference materials: SRM 610, 612, 614. Geostandards Newslett. 25, 261-266.

Zirkler, A., Johnson, T.E., White, R.W., Zack, T., 2012. Polymetamorphism in the mainland Lewisian complex, NW Scotland - phase equilibria and geochronological constraints from the Cnoc an t'Sidhean suite. J. Metamorph. Geol. 30, 865-885. 